\title{
Fluoride in Human Health and Nutrition
}

\author{
Dona Štepec $^{1,2}$ and Maja Ponikvar-Svet ${ }^{1,2, *}$ \\ ${ }^{1}$ Department of Inorganic Chemistry and Technology, Jožef Stefan Institute, Jamova cesta 39, 1000 Ljubljana, Slovenia \\ ${ }^{2}$ Jožef Stefan International Postgraduate School, Jamova cesta 39, 1000 Ljubljana, Slovenia \\ *Corresponding author: E-mail: maja.ponikvar-svet@ijs.si \\ Tel.: +38614773203
}

Received: 03-13-2019

\begin{abstract}
Fluorine is in the form of fluorides ubiquitous in nature and as such an inevitable part of our environment. In small amounts, it is known to have beneficial effects on dental health. On the other hand, excessive chronic intakes can result in adverse effects including the development of dental fluorosis in children and/or skeletal fluorosis in both children and adults. The adequate intake has been set, based on empirical observations, at $0.05 \mathrm{mg} / \mathrm{day} / \mathrm{kg}$ body weight however, the threshold between beneficial and harmful effects is narrow. Despite numerous studies, knowledge on the fluoride toxicity is still relatively poor. In this review, the role and the effects of fluoride on human health are enlightened. Some of the fluoride controversies are discussed and future research directions suggested.
\end{abstract}

Keywords: Adequate Intake; Adverse effects; Exposure; Fluoride; Fluorine; Human Health

\section{Introduction}

Fluorine is chemically most reactive of all the elements and is never or rarely encountered in nature as elemental fluorine. Two extremely rare exceptions where fluorine as gas could be trapped within the crystal of antozonite $^{1}$ and villiaumite ${ }^{2}$ were recently reported.

In combination with other elements, it comprises $0.065 \%$ of the earth's crust, being the thirteenth element in abundance on the planet. ${ }^{3}$ A brief note on terminology is in order before proceeding. In this paper, the term fluorine $(\mathrm{F})$ is used to denote the element in any of its forms and fluoride $\left(\mathrm{F}^{-}\right)$to denote the predominant chemical form of inorganic fluoride in which the element is found in nature and to which a fluoride ion selective electrode (ISE) responds.

Fluoride is an inevitable part of the biosphere and human life. The average $\mathrm{F}$ contents in soil range from about $100-600 \mathrm{mg} / \mathrm{kg}^{4,5}$ from which about $0.05-0.5 \%$ represents water soluble fluorides. ${ }^{6,7}$ Natural waters contain fluoride in varying concentrations, from trace amounts to some $\mathrm{mg} / \mathrm{l}$ and even toxic concentrations. Waters with high concentrations of fluoride are usually found at the foot of high mountains and in areas with geological deposits of marine origin. The highest fluoride levels have been recorded in the Kenyan lakes Elementaita (1640 mg/l) and Nakuru $(2800 \mathrm{mg} / \mathrm{l}) .{ }^{8}$ Fluoride concentrations in ambient air are generally lower than $1 \mu \mathrm{g} / \mathrm{m}^{3}$. ${ }^{9}$
The $\mathrm{F}$ is released into the air in a form of gaseous or particulate fluorides from natural sources, like dissolution of minerals, volcanoes, marine aerosols, and forest fires ${ }^{10,11}$ and from different industrial activities, like phosphate fertilizers and elemental phosphorus production, aluminium smelting, petroleum refining, glass, brick, and ceramic manufacturing. ${ }^{12}$

Combustion of the coal and fuel and controlled fluoridation of drinking-water supplies also contribute to the fluoride dispersion. ${ }^{13,14}$ Use of organofluorine compounds serving as pharmaceuticals, agrochemicals, refrigerants, pesticides, surfactants, fire extinguishing agents, fibers, membranes, ozone depletors, and insulating materials is in increase. Over $20 \%$ of approved pharmaceutical agents including several of the top drugs and $30-40 \%$ of commercially available agrochemicals are organofluorine compounds. ${ }^{15,16}$ All these processes and uses result in accumulation of fluoride compounds in soils, surface waters and groundwater reserves, air, and in the living organisms.

The effect of fluoride on humans is a dual one. For over eight decades, it has been recognized that small amounts of fluoride have proven benefits for dental health. This resulted in widespread use of fluorides in public health practices. ${ }^{17}$ Continuous exposure to high levels, on the other hand, leads to severe adverse effects in humans, which include the development of dental fluoro- 
sis in children or skeletal fluorosis in both, children and adults. ${ }^{17-20}$

The "optimal" (or "adequate") daily intake of fluoride for children between 0.05 and $0.07 \mathrm{mg} / \mathrm{kg}$ body weight, ${ }^{21}$ that is still accepted worldwide, is based on empirical observations. In Europe, the European Food Safety Authority (EFSA) set, because of proven benefits of small amounts of fluoride on the prevention of caries, the adequate intake (AI) of fluoride from all sources (including non-dietary sources) at $0.05 \mathrm{mg} / \mathrm{day} / \mathrm{kg}$ body weight for both children and adults. ${ }^{22}$

The primary sources of ingested fluorine for humans are water, beverages and food. ${ }^{23}$ In some countries, fluoride is deliberately added to salt ${ }^{24}$ or milk ${ }^{25}$ or public water supplies. ${ }^{26,27}$ Intake with fluoride containing dentifrices, especially in children, should be considered. ${ }^{28,29}$ In endemic fluorosis areas intake of fluoride with drinking water $^{30}$ or brick tea ${ }^{31}$ and coal-burning ${ }^{32}$ were reported to result in development of skeletal fluorosis. ${ }^{33-36}$

The adequate intake of fluoride in relation to its beneficial/adverse effects and the main sources of fluoride for humans are graphically depicted in Figure 1.

\section{Fluoride in Human Health and Nutrition}

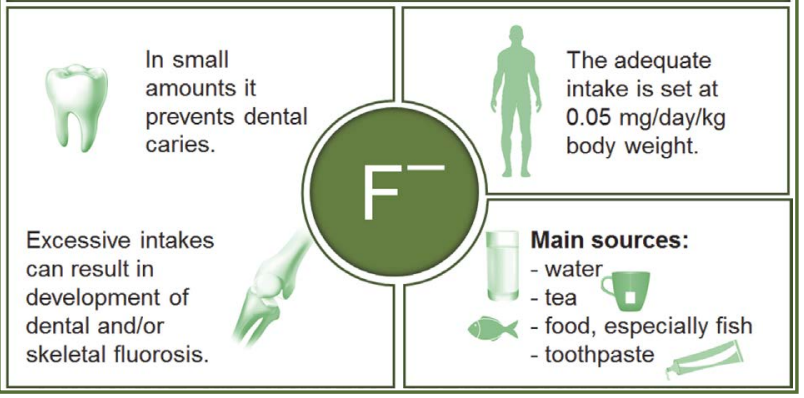

Figure 1: The adequate intake of fluoride in relation to its beneficial/ adverse effects and the main sources of fluoride for humans

Fluoride remains a subject of debate, time and time again, especially in view of the current knowledge on its possible adverse effects. The aim of this paper was twofold: first to provide the adequate background information on fluoride, which would assist in understanding its role and effects on humans, and, second, to present some of the analytical problems associated with the determination of fluoride at low levels as present in human and environmental samples. In addition, some of the fluoride controversies related to the intake of fluoride by humans and its impact on health were discussed.

\section{Beneficial Effects of Fluoride on Human Health}

Fluoride in the body is mainly associated with calcified tissue, i.e. teeth and bone which are its primary tar- gets. Beneficial effects of fluoride on dental health and on the increase of bone mineral content were suggested.

\section{1. Effects on Dental Health}

Until the 1980's the paradigm was that, to exert its maximum cariostatic effect, fluoride had to become incorporated into dental enamel during teeth development by forming hydroxyfluorapatite, which is more resistant to ingested acids or to acids generated by oral bacteria from ingested sugars. ${ }^{37}$

The new paradigm, which surprisingly slowly modified fluoride caries research, was introduced in $1981 .{ }^{38} \mathrm{It}$ explains that fluoride controls caries lesion development predominantly, if not entirely, via its topical effect on deand re-mineralization processes taking place at the interface between the tooth surface and the oral fluids. ${ }^{38,39}$ Thus, topical use of fluoride is recommended, rather than systemic.

Fluoride also interferes with the metabolism of oral microbial cells by a direct inhibition of cellular enzymes (directly or in combination with metals) or enhancing proton permeability of cell membranes in the form of hydrogen fluoride (HF) ${ }^{40,41}$

\section{2. Osteoporosis Treatment}

Since the 1960s, fluoride at high dose levels (approximately $20-30 \mathrm{mg} /$ day) has been used to treat age-dependent osteoporosis. ${ }^{12}$ Such treatment is currently not recommended. Although it may increase bone mass, the newly formed bone may lack normal structure and strength. ${ }^{42-44}$ The effect is more apparent in trabecular bone where volume and thickness is increased but without a concomitant increase in trabecular connectivity resulting in reduced bone quality. ${ }^{45}$

\section{3. Other Functions}

No average requirement (AR) of fluoride for the performance of essential physiological functions can be defined, i.e. fluoride is not essential for tooth development and has no known essential function in human growth and development. ${ }^{22} \mathrm{~A}$ statement that "no fluoride deficiency disease has ever been documented for humans" 46 is controversial. An experimental diet completely free of fluoride, capable of provoking fluoride deficiency, is difficult to obtain. ${ }^{23}$ It is also difficult to prove that it is free of fluoride, because of methodological and analytical problems in determining fluorine at low levels (see also section Fluorin(d)e analytical methods). ${ }^{23}$

\section{Adverse Effects of Fluoride}

The terms adverse effects and side effects are often used interchangeably although their meaning is different. 
Adverse effects are unintended effects that occur when a medication is administered correctly while a side effect is a secondary unwanted effect that occurs due to drug therapy. Side effects are most often mild in nature and often self resolving but adverse effects can be fatal and need to be reversed or antidote immediately. Adverse effects reduce either by reducing the dose of the medicines or by stopping the administration of the drug altogether. ${ }^{47,48}$ There are many fluoride related adverse effects. Their symptoms are nonspecific and are very much similar to the adverse and/or side effects of many other drugs, vitamins, minerals or dietary supplements. We should be therefore not surprised if fluoride related adverse effects are ascribed to other causes than fluoride.

\section{1. Symptoms of Fluoride Toxicity}

The toxicity of fluorides is due to the toxicity of the fluoride ion, a direct cellular poison that binds calcium and interferes with the activity of proteolytic and glycolytic enzymes. ${ }^{49}$ As such, the toxicity of fluoride depends on the type of compound ingested. Generally, weakly soluble or insoluble salts of inorganic fluorides, such as calcium fluoride, are less toxic than those that are more soluble, such as sodium fluoride.

\section{1. 1. Acute Exposure}

Ingested fluoride forms hydrofluoric acid at a $\mathrm{pH}$ typical of gastric juice. Acute high oral exposure to fluoride may lead to (with increased seriousness of observed symptoms) nausea, vomiting, abdominal pain, diarrhea, drowsiness, headaches, polyuria and polydipsia, coma, convulsions cardiac arrest, muscle paralysis, carpopedal spasm, spasm of the extremities occurred and death..$^{50}$ The most frequently cited range for the certainly lethal dose (CLD) of sodium fluoride is based on a review of case reports prepared by Hodge and Smith. ${ }^{51}$ It is set between 32 and $64 \mathrm{mg} / \mathrm{kg}$ body weight, which corresponds to $5-10 \mathrm{~g}$ of sodium fluoride for a $70 \mathrm{~kg}$ person). ${ }^{52}$ The probable toxic dose (PTD) for children, defined as the dose of ingested fluoride that should trigger immediate therapeutic intervention and hospitalization, because of the likelihood of serious toxic consequences, is set at $5.0 \mathrm{mg} / \mathrm{kg}$ body weight. ${ }^{51}$ Contact of liquid HF with the skin can produce severe burns; the gas is corrosive to the eyes and mucous membranes of the respiratory tract. ${ }^{53}$ The basis of the treatment of fluoride poisoning is intravenous or intramuscular calcium therapy. ${ }^{54-56}$

\section{1. 2. Chronic Exposure}

Development of dental fluorosis in children and/or skeletal fluorosis in both children and adults are the most obvious adverse effects associated with chronic excessive fluoride intakes. Both are an ancient problem because hu- mans settled since ever in areas having high concentrations of fluoride in drinking water. ${ }^{18} \mathrm{~A}$ threshold of 0.03 $\mathrm{mg} /$ day/kg body weight has been suggested for the appearance of dental fluorosis however even this intake will result in a certain, although low, level of fluorosis in a population. $^{39,57}$

Enamel fluorosis and primary dentin fluorosis would begin with the lower incisors, which complete mineralization at approximately 2-3 years of age, and end after mineralization of the third molars. ${ }^{58}$ Development of dental fluorosis has been controversial at times - on the one hand it is considered as cosmetic and, on the other, as having an adverse effect. ${ }^{59}$

The early symptoms of skeletal fluorosis include stiffness and pain in the joints. In severe cases, the bone structure may change and ligaments may calcify, with resulting impairment of muscles and pain. Constriction of vertebral canal and intervertebral foramen exerts pressure on nerves, blood vessels leading to paralysis and pain. ${ }^{60}$

A review paper in which fluoride has been linked to causing neurodevelopmental harm, ${ }^{61}$ has been a subject of debates. ${ }^{62,63}$ Recent research however evidenced, that children living in fluorosis prevalent areas have five times higher chances of developing a low intelligence quotient (IQ) than those living in less fluorosis areas ${ }^{64}$ and that IQ level was negatively correlated with fluoride concentration level in drinking water. ${ }^{65}$ Higher prenatal fluoride exposure was associated with lower scores on tests of cognitive function. ${ }^{66}$

Earlier studies suggested a protective effect of fluoride against Alzheimer's disease. ${ }^{67,68}$ This is in contrast to the later studies. The greatest impairments of structure and function may come about through the actions of charged and uncharged Al-F complexes. These complexes may cross the blood brain barrier and accumulate in the brain thus inducing brain neurotoxicity. ${ }^{69-71}$

Many other associations between increased fluoride concentrations in fluoridated drinking water and possible adverse effects were suggested, e.g., decreased total fertility rate in both females and males, ${ }^{72}$ diabetes $^{73}$ and greater impairment of thyroid function. ${ }^{74}$

\section{2. Mechanisms of Fluoride Toxicity}

Fluoride exerts different effects on the cell machinery leading to cell death, apoptosis and/or necrosis both in vivo and in vitro. Necrosis has been observed as a primary mechanism of cell death after a short exposure $(\approx 1 \mathrm{~h})$ to fluoride at relatively high concentrations $(\approx 100 \mu \mathrm{m}) .{ }^{75}$ At relatively lower concentrations (around few $\mathrm{mM}$ ) different molecular mechanisms lead to fluoride-induced cytotoxicity and eventual apoptotic cell death of different cells from different organs and tissues, e.g. lungs, kidneys, liver, brain, pancreas, thymus, endometrium, bone marrow, hair follicles, erythrocytes, leukemic cells. The molecular mechanisms underlying fluoride-induced apoptosis are 
different by nature and include the stimulation of G protein-dependent signaling systems, oxidative stress, ATP depletion, activation of the cell surface death receptors, disruption of outer mitochondria membrane, activation of caspases, alterations in the ratio of anti-apoptotic-apoptotic Bcl-2 proteins, upregulation of p53 expression, expression of apoptosis-related genes, endoplasmic reticulum stress and disturbances in protein synthesis. Reviews on the intracellular molecular mechanisms proven to be responsible for cytotoxicity and development of cell death induced by inorganic fluoride were recently reported. ${ }^{19,20}$

\section{Absorption, Metabolism, Distribution and Excretion of Fluoride}

In humans, the predominant route of fluoride absorption is via the gastrointestinal tract. Except for occupational exposure or exposure to fluoride by coal or fuel burning, exposure to fluoride by inhalation is negligible. ${ }^{14,76}$ Dermal absorption is insignificant except in cases of hydrofluoric acid burns. ${ }^{77}$

When ionic fluoride enters the acidic environment of the stomach lumen, it is largely converted to weak acid hydrogen fluoride with a $\mathrm{pKa}$ of $3.19 .^{3}$ The higher acidity of the stomach speeds up the process of absorption by passive diffusion. ${ }^{78}$ The coefficient of permeability of lipid bilayer membranes to HF is 1 million times higher than that of $\mathrm{F}^{-79}$ so there is no need for specialized enzymatic systems to be involved. ${ }^{80}$ Around $70-75 \%$ of fluoride not absorbed from the stomach will be rapidly absorbed from the small intestine in a $\mathrm{pH}$-independent process. ${ }^{81,82}$

Factors like bioavailability, amount of ingested food, emptying the stomach, the presence of the bile salts, concentrations of pepsin and pancreatin all affect the absorption from the stomach. Bioavailability (absorption and utilization) is the most important among them. Bioavailability is a measure of the amount of an administered dose that reaches the blood stream. It is $100 \%$, by definition, when a medication is administered intravenously.

The bioavailability of fluoride from sodium fluoride $(\mathrm{NaF})$ tablets, as used in many caries-prevention programmes, from a fasting stomach, is almost $100 \% .{ }^{83}$ It is also high from other soluble fluoride compounds that occur naturally or are added to drinking water and yield fluoride ions on dissolution, e.g. $\mathrm{KF}, \mathrm{Na}_{2} \mathrm{SiF}_{6}, \mathrm{H}_{2} \mathrm{SiF}_{6} .{ }^{84}$ The degree of fluoride absorption is highly affected by the presence of diet containing high contents of calcium and certain other divalent $\left(\mathrm{Mg}^{2+}\right)$ or trivalent $\left(\mathrm{Al}^{3+}, \mathrm{Fe}^{3+}\right)$ cations with which fluoride can form insoluble or poorly soluble compounds. ${ }^{85}$ In studies on adults, this bioavailability was decreased to $50-79 \%$ by co-administration of milk or calcium rich products. ${ }^{86,87}$ The poor fluoride bioavailability, in the range of $4-24 \%$, observed from food such as bone meal, fish bone meal, canned sardines and chicken bone meal, was ascribed to the high content of calcium in these foods. ${ }^{88}$ Fluoride bioavailability from typical meals eaten in different regions of India was found to be low $(2-32 \%){ }^{89}$

The halftime for fluoride absorption is approximately 30 minutes and peak plasma concentration usually occurs within $30-60$ minutes. ${ }^{83,87-91}$ Fluoride is then rapidly distributed in plasma and deposited in bone and other calcified tissues containing approximately $99 \%$ of the body's fluoride. ${ }^{92}$ The remainder of fluoride is distributed between blood and soft tissues, where a steady-state distribution between extracellular and intracellular fluids is established. ${ }^{92}$

In adults, about $50 \%$ of daily fluoride intake is associated with the calcified tissues within 24 hours and the remaining $50 \%$ is excreted in urine..$^{93}$ This 50:50 distribution is strongly shifted to greater retention in the very early and probably towards greater excretion in the later years of life. ${ }^{93}$ In adults, about $40-60 \%{ }^{94}$ of the daily intake of fluoride is excreted in the urine and in children about $45 \%{ }^{95}$ Less than $10 \%$ of the daily intake of fluoride is excreted in faeces. ${ }^{96,97}$ It was estimated that $1 \%$ or less of an ingested dose is excreted in saliva, which returns back to systemic circulation. ${ }^{98}$ Sweat provides only a minor route of fluoride excretion. ${ }^{80}$

General features of fluoride metabolism (fluoride flow through the organism) are schematically presented in Figure 2.

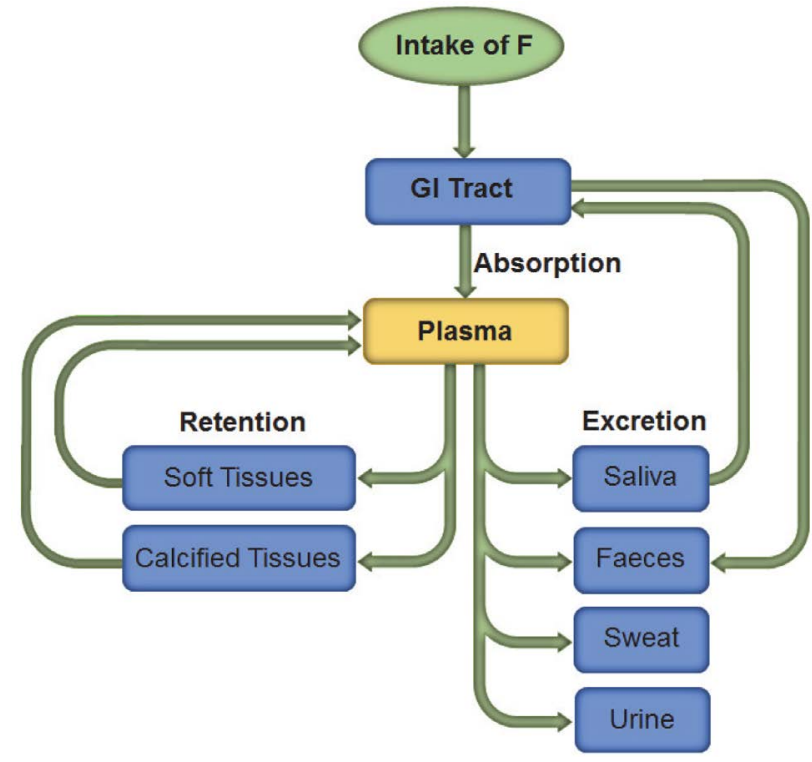

Figure 2: General features of fluoride metabolism

\section{Biomarkers of Fluoride Exposure}

Identifying and monitoring the human exposure to fluoride is of especial importance in children at the age of risk for development of dental fluorosis and in populations exposed to fluoride, i.e. with tea, via occupational exposure, in areas of the world with endemic fluorosis. 
Only absorbed fluoride is involved in the development of fluoride related adverse effects. Identification and monitoring deficient or excessive intakes of biologically available fluoride can be achieved through the use of biomarkers of fluoride exposure..$^{99}$

According to the US National Academy of Sciences (US NAS) ${ }^{100}$ definition, accepted for fluoride also by the World Health Organization (WHO), ${ }^{101}$ biomarkers are defined in a broad sense to include almost any measurement reflecting an interaction between a biological system and a potential hazard, which may be chemical, physical or biological. The measured response may be functional and physiological, biochemical at the cellular level, or a molecular interaction. For fluoride, several biological fluids and tissues can serve as biomarkers, which can be according to time-perspective classification classified as: (1) contemporary; (2) recent; and (3) historical markers. ${ }^{101}$ Extensive information on biomarkers of exposure to fluoride can be found in recent reviews. ${ }^{102-105}$ In this section, only a concise information will be presented.

\section{1. Contemporary Markers}

The concentrations of fluoride in body fluids (plasma, saliva, urine, milk, sweat) and body tissues (bone surface) were all suggested to assess present or very recent exposure to fluoride. Their fluoride content depends on the intake via water, diet, fluoride supplements and fluoride-containing dentifrices. Fluoride ion does not produce any metabolites, so it is itself the measured indicator.

Both ionic and non-ionic fluoride forms exist in plasma. The ionic fluoride form is of far greater significance when evaluating the effect of fluoride on human's health. ${ }^{106,107}$ For less than optimal water fluoride concentrations, the resting ionic fluoride concentrations in plasma ranged from 9.3 to $24.0 \mathrm{ng} / \mathrm{ml},{ }^{102}$ however, the data across various age groups enabling to determine the "usual" concentrations are insufficient. ${ }^{108}$

Urine is regarded as the most suitable biomarker for predicting fluoride intake for groups of people, but not the individuals. ${ }^{109}$ Using available data it was estimated that the ratio between the excretion and the intake of fluoride is 0.35 and 0.54 in children and adults, respectively above a threshold of total daily intake of 0.5 and $2 \mathrm{mg}$ /day, respectively. ${ }^{95}$

The whole saliva tends to be contaminated by fluoride from the oral environment. Saliva is therefore usually collected from parotid and submandibular/sublingual ducts. Fluoride concentrations in saliva closely follow the plasma concentration but at a lower level. In adults, the ratios of saliva to plasma fluoride concentrations, under resting conditions, varied from $0.32-0.55$ for parotid sali$\mathrm{va}^{110}$ and from 0.61 to 0.88 for submandibular saliva. ${ }^{98}$ In the same series of experiments, the ratio for fluoride concentrations in whole saliva and plasma was $1.10 .^{111}$ The data on a normal range of fluoride concentrations in duc- tal saliva as a basis for recommending saliva as a marker of fluoride exposure are however insufficient. ${ }^{102}$

Data on fluoride contents in surface bone, sweat and human milk are rather limited and seem unsuitable for estimating contemporary exposure of humans to fluoride. ${ }^{102}$

\section{2. Recent Markers}

In contrast to contemporary markers, whose fluoride concentrations provide a snapshot at a certain point of time and are subject to change due to recent fluoride intake and certain physiological variables, the concentration of fluoride in nails and hair is cumulative. It reflects the average level of intake over a time period taking into account their growth rate. Their major advantage over fluids and tissues as biomarkers for fluoride exposure is that they can easily be obtained in a non-invasive manner. The main issues related to fluoride in nails or hair, as biomarkers seem to be a preparation of the sample for the analysis and high possibility of external contamination. The content of fluoride in fingernails or toenails is about $0.5-5 \mu \mathrm{g} / \mathrm{g}^{112}$ and in hair about $0.2-15 \mu \mathrm{g} / \mathrm{g} .{ }^{113}$ Extremely higher values in both nails and hair were also reported in populations occupationally exposed to fluoride or populations living in fluoride endemic areas. ${ }^{112-115}$

\section{3. Historical Markers}

The main historical biomarkers that could indicate total fluoride body burden are a non-exchangeable inner compartment of bone and dentin. ${ }^{102,103}$ Inner bone and dentin both increase with age due to continuous fluoride uptake throughout life. ${ }^{106,116}$ In contrast, bulk enamel fluoride concentrations mainly reflect the level of systemic exposure to fluoride during tooth formation. ${ }^{93}$ Bone sampling is next to ethical limitations, difficult and invasive. The $\mathrm{X}$-ray screening for increased bone density could be performed, however only when the need for information justifies the radiation dose involved. In addition, bone density might not be related only to fluoride exposure or to bone fluorine content. Thus, teeth in particular third molars or premolars that are commonly extracted have emerged as potential historical biomarkers of exposure to fluoride.

\section{Fluorin(d)e Analytical Methods}

Fluoride of high concentrations in water or soil and gaseous fluoride emissions, which are all a consequence of natural or anthropogenic activities, represent a threat to vegetation and subsequently entire food chain in many parts of the world. Reliable analytical methods are therefore a prerequisite for the determination of human exposure to fluoride. The goal is to monitor the intake of fluoride and maintain it at adequate levels so that optimal protection against dental caries is achieved, without excessive intake 
resulting in the appearance of adverse effects. Basic requirements for accurate and precise determination of fluorine in any type of the sample are: (1) the sample has to be appropriately pre-treated so that the required form can be determined; (2) interfering reactions or ions have to be effectively suppressed; (3) the final concentration of fluorine must be above the detection limit of the method; and (4) the result should be reported together with a measurement uncertainty (MU) evaluated in accordance Guide to the Expression of Uncertainty in Measurement (GUM).117. ${ }^{117}$

\section{1. Forms of Fluorine}

As noticed in the Introduction of this paper, the term fluorine (F) is used to denote the element in any of its forms and fluoride $\left(\mathrm{F}^{-}\right)$to denote predominant chemical form inorganic fluoride in which the element is found in nature and to which a fluoride ion selective electrode (ISE) responds. Difference between $\mathrm{F}$ and $\mathrm{F}^{-}$in inorganic compounds, which leads to the amount of bound fluoride was discussed. ${ }^{118}$

In biological samples such as human and animal serum fluorine can be present also in the form of organic fluorine. This represents covalent fluorine that is bound to carbon in all organic fluorine compounds and results from exposure to certain fluorine-containing compounds from natural and/or industrial sources. ${ }^{119}$ Classification of different forms of fluorine in biological materials was extensively discussed. ${ }^{120-122}$

\section{2. Sample pre-treatment Procedures}

The approach to sample preparation is dependent on the type of matrix and the form of fluorine to be determined. Fluorine in samples can be determined as ionic, total or covalent fluorine.

\section{2. 1. Ionic Fluoride}

The concentration of fluoride in water can usually be determined directly without pre-treatment. Dissolution in water prior to fluoride measurement is a valid approach also for determination of soluble fluorides in solid samples. During interpretation of the results it is necessary to consider equilibria between $\mathrm{F}^{-}$and ions with which fluoride forms soluble or poorly soluble compounds, in relation to the employed analytical technique, e.g. $\mathrm{Al}^{3+}, \mathrm{Fe}^{3+}$, $\mathrm{Si}^{4+}, \mathrm{Sn}^{4+}, \mathrm{Zr}^{4+} .85$

Methods for determining gaseous fluorides are generally based on the absorption of gaseous fluorides into a train of absorbing solutions, or collection on a filter with a treated pad and subsequent determination of fluoride.

\section{2. 2. Total Fluorine}

Samples containing non-ionic inorganic fluoride and/or organic fluorine have to be decomposed prior to the measurement. Extraction or digestion with acids or mixtures of acids or digestion with alkaline solutions might dissolve the $\mathrm{F}$ in the samples only to varying degrees. Results of such studies are difficult or even impossible to compare, especially because there is no certified reference material (CRM) available to support the results of such measurements. Therefore, prior to quantification, samples must undergo a total decomposition to assure release of the inorganic or organic bound $\mathrm{F}$ to $\mathrm{F}^{-}$and bring the solid sample in a water soluble form.

In the classical Willard-Winter ${ }^{123}$ distillation procedure introduced in 1933, decomposition of compounds and separation of resulting fluoride from interfering substances take place concurrently. This technique and its modifications ${ }^{124-126}$ have provided a wealth of information through the middle decades of the $20^{\text {th }}$ century but, mostly because of its cumbersome procedure, have been replaced by simpler methods, like pyrohydrolysis ${ }^{127,128}$ or diffusion methods. ${ }^{129-131}$ Commonly used procedures nowadays for total sample decomposition involve oxygen bomb combustion, ${ }^{132,133}$ open ashing ${ }^{134,135}$ fusion with alkali metal hydroxides or carbonates ${ }^{136,137}$ and microwave acid digestion. ${ }^{138,139}$

Reactions proceeding during decomposition of metal fluorides by pyrohydrolysis, oxygen bomb combustion and alkaline carbonate fusion and their related thermochemistry were discussed in our recent papers. ${ }^{140,141} \mathrm{Calci}$ um and magnesium fluoride, which can be in variable amounts present also in human, animal, vegetation and other environmental samples, were suggested as the most resistant ones to decompose among all the metal fluorides studied.

\section{2. 3. Covalent Fluorine}

The basis for determination of organic fluorine in biological materials such as blood serum and soft tissues rely on the determination of total $\mathrm{F}$ with respect to $\mathrm{F}^{-}$using total decomposition methods. As a faster alternative for sample preparation use of sodium biphenyl was described. ${ }^{142}$ The method relies on reductive cleavage of the $\mathrm{C}-\mathrm{F}$ bond, which is the strongest bond in organic chemistry ${ }^{143,144}$.

\section{3. Methods for Determination of Fluoride}

The methods for determination of $\mathrm{F}^{-}$range from classical volumetric ${ }^{123-125}$ to spectrophotometric ${ }^{125,126}$ and fluorometric ${ }^{145,146}$ methods. A breakthrough in the analytical chemistry of fluorine was in 1966 when the fluoride ion selective electrode (ISE) was introduced by Frant and Ross ${ }^{147}$. The electrode consists of a single crystal lanthanum fluoride $\left(\mathrm{LaF}_{3}\right)$ doped with europium (II) fluoride to improve its conductivity. The electrode is highly selective and covers a wide range of concentrations ( $1 \mathrm{~mol} / \mathrm{l}$ to $10^{-5}$ $\mathrm{mol} / \mathrm{l})$. The limit of detection of fluoride ISE is limited by 
the solubility of $\mathrm{LaF}_{3}$ to $\approx 0.02 \mathrm{mg} / \mathrm{l} .{ }^{148}$ In our laboratory we developed a multiple known standard addition method for determination of fluoride based on spiking the samples with known amount of fluoride prior to the measurement. In this way the limit of detection (LOD) of $\approx 0.01 \mathrm{mg} / \mathrm{l}$ was achieved. ${ }^{149}$

Various chromatographic methods for fluoride determination include ion chromatography (IC), ${ }^{150}$ gas chromatography (GC) $)^{151,152}$ and high-performance liquid chromatography (HPLC). ${ }^{153}$ The main issues related to the use of IC are that fluoride peak tends to overlap with the water negative dip and that monocarboxylic acids interfere because of co-elution with fluoride or only partial resolution. This makes IC suitable for determination of $\mathrm{F}^{-}$in aqueous samples. ${ }^{154-157}$ Use of GC has been reported for determination of fluoride in various kinds of biological matrixes however it is time consuming and requires trained personnel. ${ }^{158}$ Use of HPLC with reverse-phase mode columns for determination of fluoride is rarely reported. ${ }^{153}$

Determination of fluorine by atomic absorption spectrometry (AAS), laser-induced breakdown spectroscopy (LIBS), inductively coupled plasma optical emission spectrometry (ICP-OES), or inductively coupled plasma mass spectrometry (ICP-MS) is almost impossible task because of high excitation and ionization potential (17.42 $\mathrm{eV}$ ) of $\mathrm{F}$ and the location of its resonance line in the vacuum ultraviolet range $(95 \mathrm{~nm}){ }^{159}$ Use of molecular absorption spectrometry (MAS) methods with high-resolution continuum source (HR-CS) to determine fluorine through the absorption of diatomic molecules, such as $\mathrm{CaF}$ or $\mathrm{GaF}$ was reviewed. ${ }^{160}$ Its major limitation is that online coupling with chromatographic separation methods is not possible. Use of mass-shift strategy using tandem inductively coupled plasma quadrupole mass spectrometry (ICP-MS-MS) was reported for the determination of fluorine. ${ }^{161}$

Less frequently used methods for determination of fluorine include polarography, ${ }^{162}$ voltammetry, ${ }^{163}$ sensors, ${ }^{164}$ capillary zone electrophoresis (CZE) ${ }^{165}$ near infrared spectroscopy (NIR), ${ }^{166}{ }^{19} \mathrm{~F}$-nuclear magnetic resonance $\left({ }^{19} \mathrm{~F}-\mathrm{NMR}\right),{ }^{167}$ neutron activation analysis (NAA) ${ }^{168}$ and others.

\section{4. Measurement Uncertainty Evaluation}

A truly informed decision, based on a measurement result, can only be made with the consideration of the MU. ${ }^{169}$ Classically in analytical chemistry, the MU has been expressed as one standard deviation, thus including only random effects. A superior, more comprehensive approach is outlined in the definite document in the field of metrology GUM. ${ }^{117}$ In this approach, in addition to random effects, also systematic effects are taken into account and all uncertainty components of each step of analytical procedure are identified, quantified and traceable ${ }^{169}$ to the
SI units. All these contributors are then combined and the MU is reported as an expanded uncertainty, which corresponds to the $95 \%$ level of confidence. ${ }^{117}$

Unfortunately, the only paper reporting procedure for evaluation of the MU according to the GUM for $\mathrm{F}$ is on determination of fluoride in water. ${ }^{170}$ Recently we suggested a procedure for the $\mathrm{MU}$ evaluation for determination of F in solid samples, which must undergo a total decomposition before the measurement. ${ }^{171}$ This makes evaluation of the MU much more complex, because: (1) in addition to the uncertainty of the measurement step also uncertainty of the decomposition step must be included; and (2) transformation of the sample from one chemical form to another cannot be traceable to any reference and therefore the highest form of traceability can be achieved by the use of matrix matched CRM. ${ }^{172}$

\section{Sources of Oral Exposure to Fluoride}

Knowing total fluoride contents contributing to the oral exposure to fluoride, e.g. water and beverages, different food items, dental products and alternatives to water fluoridation, like fluoridated salt or milk and fluoride supplements, can assist in estimating the total daily intake of fluoride and the measure of exposure.

\section{1. Drinking Water}

Natural waters aimed also for human consumption contain varying concentrations of fluoride, from trace amounts to some $\mathrm{mg} / \mathrm{l}$ and even toxic concentrations. Waters with high concentrations of fluoride are usually found at the foot of high mountains and in areas with geological deposits of marine origin. Large variations in natural fluoride contents of drinking water between and within countries can be observed. ${ }^{173,174}$

The WHO, based on earlier documents (from 1984, 1993 and 2004), ${ }^{77,175,176}$ set in 2010 the guideline value for fluoride in drinking water, by taking into account drinking water consumption, at $1.5 \mathrm{mg} / \mathrm{l} .{ }^{26}$ This is in conflict with the WHO recommendation from 1994 according to which the absolute upper limit for fluoride in drinking water is 1.0 $\mathrm{mg} / \mathrm{l}^{99}$ In the European Union (EU) drinking, water for human consumption may not contain more than 1.5 $\mathrm{mg} / \mathrm{l} .{ }^{177}$ The earlier recommended optimal fluoride concentration for fluoridated water in the US was recently reduced from $0.7-1.2 \mathrm{mg} / \mathrm{l}$ to $0.7 \mathrm{mg} / \mathrm{l} .{ }^{178}$ It has to be pointed out that few subjects in medicine have proved more controversial than fluoridation of public water supplies. The controversy is illustrated by the fact that, while the US Centers for Disease Control and Prevention (CDC) claimed that water fluoridation is one of the ten great public health achievements in the US during the $20^{\text {th }}$ century, ${ }^{179}-69 \%$ of the population receives fluoridated drinking water ${ }^{27}-$ water fluoridation is banned in most of Europe. ${ }^{173}$ 
Use of bottled water is in increase. In the EU, bottled water exceeding fluoride concentration of $1.5 \mathrm{mg} / \mathrm{l}$ shall bear on the label "contains more than $1.5 \mathrm{mg} / \mathrm{l}$ of fluoride: not suitable for regular consumption by infants and children under 7 years of age" and a maximum limit of $5 \mathrm{mg} / \mathrm{l}$ is set for naturally present fluoride. ${ }^{180}$ The concentration of fluoride in bottled water in the US depends on whether fluoride is naturally present or added and on the annual average of maximum daily air temperatures at the location where the bottled water is sold at retail. Thus, the concentrations of fluoride in bottled water packaged in the US and imported water should not exceed 2.4 and $1.4 \mathrm{mg} / \mathrm{l}$, respectively. ${ }^{181}$

\section{2. Tea and Beverages}

The tea plant (Camellia sinensis L.; family Theacea) (Figure 3) is known to take up fluoride from the soil and accumulate it in the leaves. The total fluorine content of the leaves typically ranges between 50 and $900 \mathrm{mg} / \mathrm{kg} .{ }^{182-186}$ About $25-100 \%$ of fluorine is released during the infusion, thus the infusions may contain about 0.3 to $8.8 \mathrm{mg} / \mathrm{l}$ of fluoride, depending also on the amount of dry tea used, the granulation of the tea, the concentration of fluoride in the added water, the presence of milk, duration of infusion, etc. ${ }^{182-186}$ Concentrations of fluoride in ready-to-drink tea were reported to range between 0.01 to $4.1 \mathrm{mg} / 1^{187-189}$ and in one study an extraordinarily high average of $25.7 \mathrm{mg} / \mathrm{l}$ of fluoride was reported. ${ }^{190}$

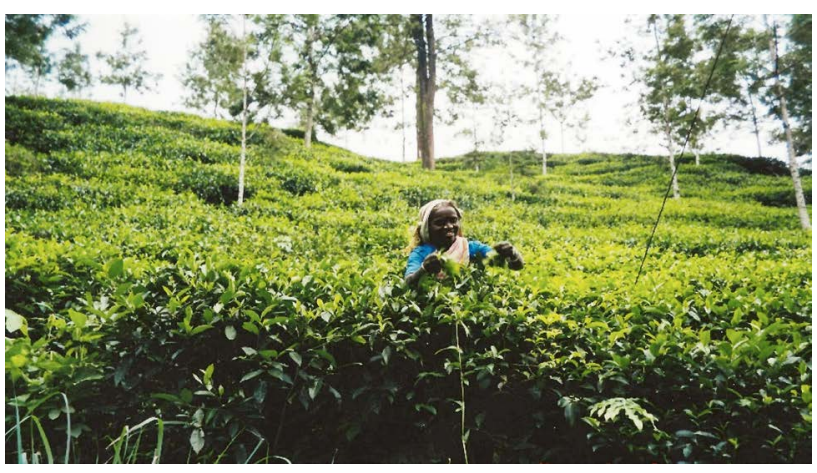

Figure 3: Tea harvesting in Sri Lanka (Photo: M. Ponikvar-Svet)

Concentrations of fluoride in soft drinks, e.g. nectars, juices, juice drinks, ranged between $0.10-2.0 \mathrm{mg} / \mathrm{l}$ in Portugal, ${ }^{191} 0.07-1.14 \mathrm{mg} / \mathrm{l}$ in the Canary Islands, ${ }^{192} 0.02-$ $2.80 \mathrm{mg} / \mathrm{l}$ in the US ${ }^{193}$ and $0.07-1.42 \mathrm{mg} / \mathrm{l}$ in Mexico. ${ }^{194}$ Concentrations of fluoride in juices and juices-flavoured drinks for infants and children ranged between $0.01-0.25$ $\mathrm{mg} / \mathrm{l}$ in Poland ${ }^{195}$ and $0.11-1.81 \mathrm{mg} / \mathrm{l}$ in the US. ${ }^{196}$

Carbonated soft drinks analysed in Europe contained $0.10-0.38 \mathrm{mg} / \mathrm{l}$ of fluoride. ${ }^{191,192}$ The observed concentrations were higher in the US and Mexico and ranged from 0.02 to $1.28 \mathrm{mg} / \mathrm{l}^{197}$ and from 0.07 to $1.62 \mathrm{mg} / \mathrm{l}$, respectively. ${ }^{194}$
The range of fluoride concentration in beer available in Europe was $0.067-1.12 \mathrm{mg} / \mathrm{l}^{198-200}$ High concentrations, 1.77 and $1.66 \mathrm{mg} / \mathrm{l}$ of fluoride, were determined in beer from Ireland and the US, respectively. ${ }^{194,200}$ Wide variations in fluoride concentrations found in different studies can be explained either by low natural presence of fluoride or by high presence of fluoride due to naturally occurring or artificially added fluoride in water used in manufacturing process.

Fluoride concentration in bottled wines of the different types from the Canary Islands ranged between 0.03 and $0.70 \mathrm{mg} / \mathrm{l}^{201-203}$ and from Turkey between $0.02-0.38$ $\mathrm{mg} / \mathrm{l} .{ }^{204}$ High concentrations of fluoride between 0.23 to $2.80 \mathrm{mg} / \mathrm{l}$ in nineteen California wines apparently resulted from the use of cryolite as a pesticide. ${ }^{205}$

\section{3. Milk and Baby Formulas}

The reported concentrations of fluoride in commercially available milk were generally low and did not exceed $0.1 \mathrm{mg} / \mathrm{l}^{206,207}$ High concentration of fluoride in pasture or drinking water of livestock might however contribute to fluoride levels in milk of different cattle. ${ }^{208-210}$ Reported fluoride concentrations in soya milk varied between 0.01 and $0.964 \mathrm{mg} / \mathrm{l}^{211-213}$

Fluoride concentrations in breast milk are generally low even at very high intakes of fluoride by mothers. The average concentrations range from 0.002 to $0.073 \mathrm{mg} / \mathrm{l}^{214}$ Surprisingly high concentrations of fluoride in breast milk were determined in one study conducted in the high altitude $(>2000 \mathrm{~m})$. In that study the fluoride contents of breast milk of mothers with dental fluorosis and children with dental fluorosis, in the high altitude ranged between $0.13-0.99 \mathrm{mg} / \mathrm{l}$ (average $0.55 \mathrm{mg} / \mathrm{l}$ ), while breast milk mothers in the control group without dental fluorosis contained $0.001-0.10 \mathrm{mg} / \mathrm{l}$ (average $0.006 \mathrm{mg} / \mathrm{l}$ ). ${ }^{215}$ These results suggested that there is more to understand about the factors affecting the level of fluoride in breast milk, such as the effect of altitude. ${ }^{216}$

Concentrations of fluoride between 0.01 and 0.75 $\mathrm{mg} / \mathrm{l}$ were reported in a review on fluoride concentration in infant formula products reconstituted with fluoride-free water according to the manufacturer's instructions. ${ }^{217}$ When formulae were prepared with water of differing fluoride concentrations, the fluoride concentration was found to be a simple linear function of water fluoride concentration..$^{217}$

\subsection{Foods}

The fluorine contents in different foods and drinks in this paper are illustrated using the data from the USDA National Fluoride Database ${ }^{218}$ and the United Kingdom (UK) Fluoride Database. ${ }^{219,220}$ The USDA Database ${ }^{218}$ is based on the data extracted from reviews of existing scientific literature and unpublished results mainly from the 
Table 1: The averages and the ranges of total fluorine contents $\left(w_{\mathrm{F}}\right)$ in different food groups on a fresh weight basis listed in the USDA National Fluoride Database $\mathrm{2}^{218}$ and UK Fluoride Database ${ }^{219,220}$ analyzed as ready-to-eat items

\begin{tabular}{|c|c|c|c|c|c|c|}
\hline & $n_{\text {products }}{ }^{\mathrm{a}}$ & $\begin{array}{c}\text { USDA Database } \\
w_{\mathrm{F}}(\mu \mathrm{g} / \mathbf{1 0 0 g}) \\
\text { Average (SD) }\end{array}$ & Range & $n_{\text {products }}{ }^{\mathrm{a}}$ & $\begin{array}{l}\text { UK Database } \\
w_{\mathrm{F}}(\mu \mathrm{g} / 100 \mathrm{~g}) \\
\text { Average }(\mathrm{SD})\end{array}$ & Range \\
\hline Fruits, nuts ${ }^{\mathrm{b}}$ & 19 & $5(3)$ & $1-12$ & 19 & $4(4)$ & $1-19$ \\
\hline Fats, oils & 6 & $9(10)$ & $1-25$ & 8 & $4(8)$ & $0-17$ \\
\hline Vegetables, spices, herbs ${ }^{c}$ & 37 & $17(15)$ & $1-49$ & 23 & $7(6)$ & $1-19$ \\
\hline Meat and products & 17 & $24(14)$ & $4-48$ & 25 & $7(7)$ & $2-24$ \\
\hline Milk, egg and products ${ }^{\mathrm{d}}$ & 13 & $12(13)$ & $1-35$ & 28 & $7(13)$ & $1-59$ \\
\hline Cereal products & 9 & $27(18)$ & $6-51$ & 16 & $31(21)$ & $4-57$ \\
\hline Breakfast cereals & 12 & $44(19)$ & $17-72$ & 12 & $26(30)$ & $4-75$ \\
\hline Soups, sauces, gravies & 22 & $39(34)$ & $1-132$ & 11 & $14(21)$ & $1-49$ \\
\hline Sweets, snacks & 46 & $33(26)$ & $1-106$ & 81 & $15(19)$ & $1-90$ \\
\hline Beverages, water & 132 & $48(34)$ & $2-204$ & 22 & $13(11)$ & $0-45$ \\
\hline Tea & 25 & $262(136)$ & $9-584$ & 3 & $30(27)$ & $12-61$ \\
\hline Fish, shellfish and products & 7 & $111(87)$ & $18-210$ & 13 & $149(298)$ & $8-1054$ \\
\hline Dishes & 28 & $37(20)$ & $5-84$ & 30 & $15(12)$ & $1-51$ \\
\hline Infant food and drinks & 50 & $12(14)$ & $0-67$ & 251 & $15(21)$ & $1-120$ \\
\hline
\end{tabular}

${ }^{a}$ Number of analyzed items ${ }^{\mathrm{b}}$ The highest content was not considered $\left(234 \mu \mathrm{g} / 100 \mathrm{~g}\right.$ of $\mathrm{F}$ in raisins) ${ }^{\mathrm{c}}$ The highest content was not considered (115 $\mu \mathrm{g} / 100 \mathrm{~g}$ of $\mathrm{F}$ in french fries, McDonald's) d The highest content was not considered (112 $\mu \mathrm{g} / 100 \mathrm{~g}$ of F in cream substitute, powdered)

period between 1977 and 2003. The more recent UK Database $^{219,220}$ was generated in a period between 2003 and 2015 through a range of research projects.

These databases arrange food and drink items in different groups, therefore the F contents are difficult to compare. Thus, we re-positioned all food items and drinks from both databases within the same groups. The averages and the ranges of total fluorine contents in these food groups are presented in Table 1.

The presented data compiled from the original databases (Table 1) show a wide variation in fluorine contents within and between individual food groups (see SDs and ranges). The average content of $\mathrm{F}$ of all food groups is 2.7fold higher in the USDA Database than in the UK Database, this is $47 \mu \mathrm{g} / 100 \mathrm{~g}$ as opposed to $17 \mu \mathrm{g} / 100 \mathrm{~g}$. The average content of F in the USDA Database remains 1.9fold higher than in the UK Database even if tea is taken aside. This can be explained by different levels of fluoride in water used for the preparation of the products requiring water; results obtained using tap water containing $0.71 \mathrm{mg}$ $\mathrm{F}^{-} / 1$ are reported in the USDA Database and results reported using tap water containing $0.05-0.13 \mathrm{mg} \mathrm{F}^{-} / 1$ were selected from the UK Database. The fluorine contents in individual food groups were, for easier visualization presented also in Figure 4.

The content of fluorine in food is generally below 50 $\mu \mathrm{g} / 100 \mathrm{~g}$ (Figure 4 and Table 1). Exceptions to this include: (1) processed food (breakfast cereals, sweets, snacks, sauces) and beverages which can contain considerable amounts of fluorine if fluoridated water is used during the production process or for their preparation; (2) tea, which can during infusion release high amounts of fluoride accumulated in the leaves; and (3) fish and shellfish which might

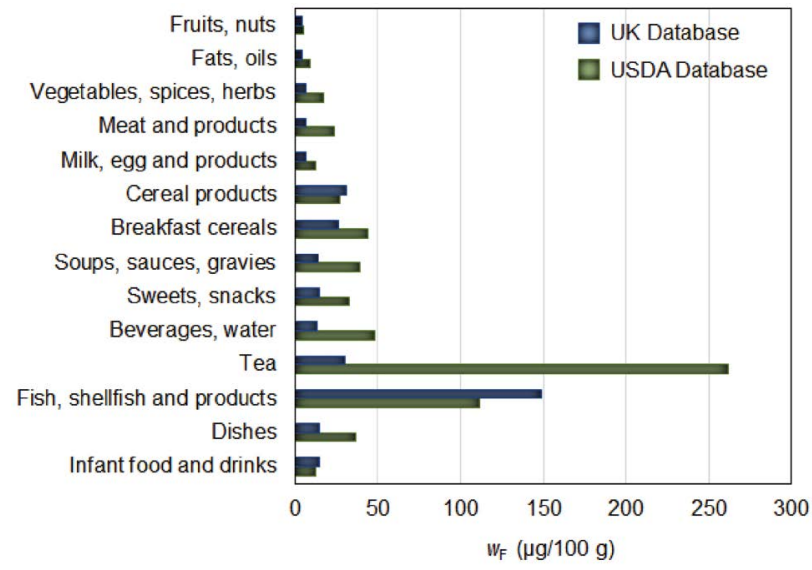

Figure 4: The average contents of fluorine in different food groups on a fresh weight basis listed in the USDA National Fluoride Database $^{218}$ and the UK Fluoride Database ${ }^{219,220}$ analyzed as ready-toeat items

contain high fluorine contents, if analyzed samples, due to mechanical deboning, contain bones and exoskeleton remains, where fluoride is accumulated from the sea.

Finally, it is worth mentioning that in addition to these databases many studies reported the contents of total and/or free fluoride in different food items. ${ }^{221-227}$ The results of these studies are difficult to compare, because the determined level of fluorine in food is among other influenced by: (1) the locality in which the food is grown; (2) the differences in the amount of fertilizer and pesticides applied or differences in feeding routine; (3) the type of processing the food receives; (4) the amount of water and the fluoride content of water used in their preparation; (5) different sample pre-treatment procedures; and (6) the differences in the analytical procedures. In addition, the re- 
sults are not reported according to the Guide to the Expression of Uncertainty in Measurement (GUM). ${ }^{17117}$

\section{5. Fluoride Containing Dental Products}

Fluoride containing dental products (toothpaste, rinses and gels) although not considered as a dietary source, can increase the total oral intake of fluoride considerably, especially when used inappropriately. Because of poor control of the swallowing reflex, fluoride ingestion by young children needs to be during the first six years of life carefully controlled and the best balance between risk and efficacy might be achieved by using small amounts of high fluoride toothpaste under close supervision from parents. ${ }^{28,29}$ Fluoridated toothpaste (Figure 5) for children usually contains 250 to $500 \mu \mathrm{g} / \mathrm{g}$ of fluoride ${ }^{228}$ and for adults from $1000-1500 \mu \mathrm{g} / \mathrm{g}$ of fluoride. ${ }^{229}$

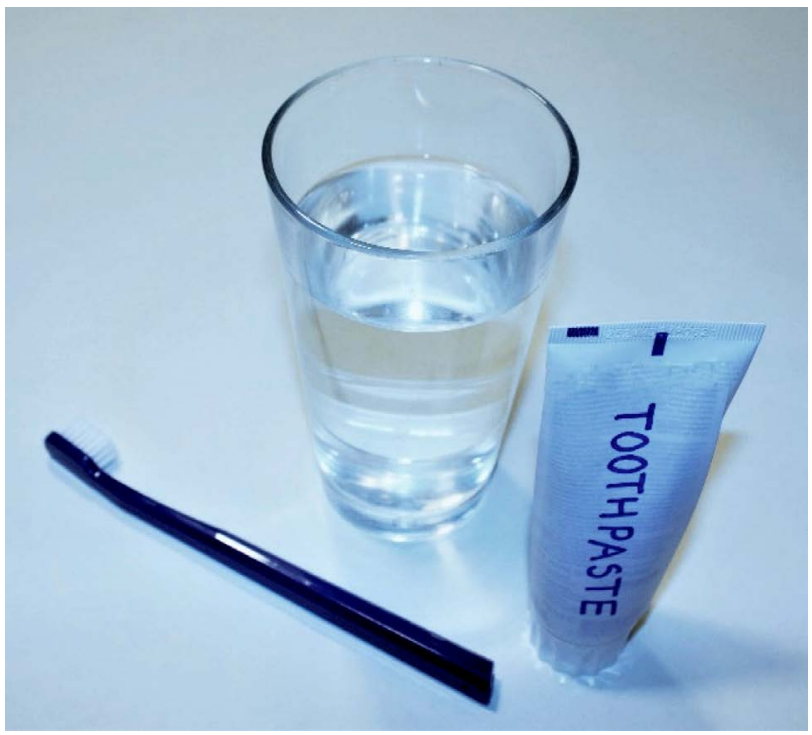

Figure 5: Toothpaste contributes significantly to the daily intake of fluoride especially in children (Photo: M. Ponikvar-Svet)

\section{6. Fluoridated Salt or Milk and Fluoride Supplements}

Salt fluoridation which begun in 1956 in Switzerland ${ }^{24}$ is practiced as an alternative to water fluoridation. It has been estimated that between 40 million and 280 million people worldwide use fluoridated salt, mainly in European, South American and Central American countries, some Asian countries, including Cambodia and Laos and in Africa, Madagascar. For salt fluoridation, sodium fluoride and potassium fluoride are mostly used at a concentration of $250-300 \mathrm{mg} / \mathrm{kg}$ of fluoride. ${ }^{231,232}$

Milk as a relatively cost-effective vehicle for fluoride delivery in the prevention of dental caries was first proposed in the $1950 \mathrm{~s} .{ }^{25}$ As suggested in an update to a Co- chrane Review ${ }^{233}$ first published in $2005,{ }^{234}$ there is low quality evidence to suggest fluoridated milk may be beneficial to schoolchildren, contributing to a substantial reduction in dental caries in primary teeth.

Systematic reviews ${ }^{235,236}$ have shown that there is weak and inconsistent evidence to demonstrate that fluoride supplements administered in the form of tablets, drops, lozenges or chewing gums can effectively prevent caries in primary teeth. However, there is strong evidence that fluoride supplements can prevent caries in permanent teeth. The use of fluoride supplements was associated with a high risk of mild-to-moderate fluorosis. Current recommendations on their use are controversial - on one hand European Academy of Paediatric Dentistry (EAPD) recommends that fluoride tablets and fluoride drops could be considered on an individual basis for children at high risk of carie ${ }^{237}$ and, on the other hand, the American Academy of Pediatric Dentistry (AAPD) recommends that fluoride dietary supplements should be considered for children at caries risk who drink fluoride-deficient (less than $0.6 \mathrm{mg} / \mathrm{l})$ water. ${ }^{238}$

\section{Daily Intake of Fluoride}

Estimating exposure to fluoride, especially in children, is of crucial importance to avoid potential problems associated with too low or too high intakes. The adequate intake (AI) of fluoride from all sources (including non-dietary sources) is because of proven benefits of fluoride on dental health set at $0.05 \mathrm{mg} / \mathrm{day} / \mathrm{kg}$ body weight for both children and adults. ${ }^{22}$ Major contributors to the oral intake of fluoride are drinking water, tea, beverages, foods and fluoride containing dental products. ${ }^{23}$ The contribution of inhaled airborne fluoride, or fluoride from the soil, to the total fluoride intake is, under normal conditions, small ${ }^{23}$ and is beyond the scope of this paper.

There is a lack of data on the total fluoride intake from dietary and non-dietary sources based on analyses of individual actual diets. ${ }^{22}$ The estimates are often based on the estimates of quantities of foods consumed, such as standard food tables or questioners, rather than actual quantities of food consumed. ${ }^{22}$ This might result in under or over estimates of actual fluoride intakes because of wide variations in fluoride contents of individual food items.

\section{1. Fluoride Intake in Children}

As reported the prevalence of enamel fluorosis is over the last three decades on the rise in the United States (US). ${ }^{58,239,240}$ The cases reported include also more cases of moderate-to-severe fluorosis. ${ }^{58,239-241}$ One of the possible reasons might be that fluoride appears to be more readily available for consumption nowadays during the critical window when enamel is most susceptible to fluorosis. ${ }^{240}$ 
Table 2: Estimated intakes of total fluoride from diet and toothpaste for children expressed as averages in mg/day/kg body weight by $\mathrm{F}^{-}$concentration in water $\left(\gamma\left(\mathrm{F}^{-}\right)_{\text {water }}\right)$ and age groups; fluoride intake by breastfed infants is not listed

\begin{tabular}{|c|c|c|c|c|c|c|}
\hline \multirow[b]{2}{*}{ Age (yr.) } & \multirow[b]{2}{*}{$\gamma\left(\mathbf{F}^{-}\right)_{\text {water }}(\mathrm{mg} / \mathbf{l})$} & \multicolumn{3}{|c|}{ mg/day/kg body weight } & \multirow[b]{2}{*}{ Note } & \multirow[b]{2}{*}{ Ref } \\
\hline & & Food (SD) & Toothpaste (SD) & Total (SD) & & \\
\hline \multicolumn{7}{|c|}{ Nonfluoridated water } \\
\hline $2-6$ & 0.08 & $0.017(0.009)$ & NA & NA & $\mathrm{a}$ & 242 \\
\hline up to 4 & 0.04 & 0.006 & 0.055 & 0.061 & $\mathrm{~b}$ & 243 \\
\hline up to 4 & 0.04 & 0.011 & NA & 0.011 & $\mathrm{~b}, \mathrm{c}$ & 243 \\
\hline 4 & $0.04-0.07$ & $0.033(0.012)$ & $0.016(0.011)$ & $0.050(0.019)$ & a & 244 \\
\hline 4 & $0.06-0.07$ & $0.033(0.012)$ & $0.029(0.016)$ & $0.062(0.022)$ & $\mathrm{a}$ & 244 \\
\hline 4.75 & $0.08-0.015$ & $0.02(0.01)$ & NA & NA & $\mathrm{b}, \mathrm{d}$ & 245 \\
\hline 5.25 & $0.08-0.015$ & $0.018(0.018)$ & NA & NA & $b, d$ & 245 \\
\hline $6-7$ & 0.08 & $0.008(0.004)$ & $0.023(0.026)$ & $0.031(0.025)$ & a & 246 \\
\hline 8 & $0.04-0.07$ & $0.033(0.012)$ & $0.012(0.007)$ & $0.048(0.038)$ & a & 244 \\
\hline \multirow[t]{2}{*}{8} & $0.06-0.07$ & $0.030(0.014)$ & $0.013(0.006)$ & $0.043(0.016)$ & $\mathrm{a}$ & 244 \\
\hline & Average (SD) & $0.021(0.011)$ & $0.023(0.015)$ & $0.044(0.018)$ & & \\
\hline \multicolumn{7}{|c|}{ Fluoridated water } \\
\hline up to 4 & 0.64 & 0.011 & 0.037 & 0.048 & $\mathrm{~b}$ & 243 \\
\hline up to 4 & 0.64 & 0.015 & NA & 0.015 & $\mathrm{~b}, \mathrm{c}$ & 243 \\
\hline $2-5$ & $0.5-0.7$ & $0.033(0.013)$ & $0.01(0.01)$ & $0.043(0.016)$ & $\mathrm{b}$ & 247 \\
\hline $2-6$ & $0.6-0.8$ & 0.028 & $0.036(0.028)$ & $0.064(0.035)$ & a & 248 \\
\hline $3-4$ & $<0.7$ & $0.02(0.01)$ & 0.00 & 0.02 & a & 249 \\
\hline $3-4$ & $0.7-1.2$ & $0.04(0.01)$ & 0.01 & 0.05 & a & 249 \\
\hline 4 & 0.64 & $0.025(0.010)$ & 0.046 & $0.071(0.036)$ & $\mathrm{b}$ & 250 \\
\hline 4 & $0.8-1.0$ & $0.041(0.026)$ & 0.018 & $0.059(0.029)$ & $\mathrm{a}$ & 244 \\
\hline $4-6$ & 1 & $0.027(0.014)$ & 0.030 & $0.058(0.042)$ & $\mathrm{b}, \mathrm{e}$ & 251 \\
\hline $4-6$ & 1 & $0.026(0.014)$ & 0.028 & $0.054(0.034)$ & $\mathrm{b}, \mathrm{e}$ & 251 \\
\hline $6-7$ & 0.47 & $0.016(0.005)$ & 0.022 & $0.038(0.038)$ & $\mathrm{a}$ & 246 \\
\hline $6-7$ & 0.82 & $0.025(0.014)$ & 0.022 & $0.047(0.008)$ & a & 246 \\
\hline \multirow[t]{2}{*}{8} & $0.8-1.0$ & $0.041(0.039)$ & 0.015 & $0.057(0.045)$ & a & 244 \\
\hline & Average (SD) & $0.027(0.010)$ & $0.023(0.013)$ & $0.048(0.017)$ & & \\
\hline \multicolumn{7}{|c|}{ High fluoridated water } \\
\hline $3-4$ & $>1.2$ & $0.05(0.03)$ & $0.01(0.02)$ & 0.07 & a & 249 \\
\hline 4 & $2.0-3.0$ & $0.362(0.181)$ & $0.022(0.014)$ & $0.385(0.184)$ & a & 244 \\
\hline 8 & $2.0-3.0$ & $0.307(0.120)$ & $0.019(0.016)$ & $0.326(0.128)$ & $\mathrm{a}$ & 244 \\
\hline 11 & 5 & $0.29(0.10)$ & 0.017 & 0.307 & $\mathrm{~b}, \mathrm{f}$ & 30 \\
\hline 12 & 5 & $0.35(0.10)$ & 0.017 & 0.367 & $\mathrm{~b}, \mathrm{f}$ & 30 \\
\hline \multirow[t]{2}{*}{12} & 5 & $0.36(0.20)$ & 0.017 & 0.377 & $\mathrm{~b}, \mathrm{f}$ & 30 \\
\hline & Average (SD) & $0.287(0.120)$ & $0.017(0.004)$ & $0.305(0.119)$ & & \\
\hline
\end{tabular}

\footnotetext{
${ }^{a}$ Questionnaire ${ }^{b}$ Double plate ${ }^{c}$ No tooth brushing as well as non-fluoride-toothpaste user ${ }^{\mathrm{d}}$ Measured at a baseline and after 6 months ${ }^{\mathrm{e}}$ Weekly
} variation ${ }^{\mathrm{f}}$ The intake from toothpaste was estimated as an average of the intakes reported in refs. 244,249

Estimates for the total fluoride intakes for children from food and toothpaste, by water fluoridation status and the age groups as reported in the last decade are presented in Table 2. The data for breastfed infants, who may receive lower amounts of fluoride than those listed in Table 2, are not included.

Wide variations in the intakes of fluoride within and between studies are evident from Table 2 . This can be ascribed to the factors like: (1) considerable differences in the contents of fluoride in different food items; (2) large variation in the quantities consumed; (3) differences between the age groups studied; and (4) differences in the analytical methods used for total fluoride determination.
The average total daily intakes of fluoride in children were estimated using data listed in Table 2 and illustrated in Figure 6.

The estimated average total daily intake of fluoride from all studies in nonfluoridated areas is slightly higher than in fluoridated areas $(0.044$ and $0.048 \mathrm{mg} / \mathrm{kg}$ body weight (Figure 6 and Table 2). Neither of them exceeds the adequate intake of $0.05 \mathrm{mg} / \mathrm{day} / \mathrm{kg}$ body weight. Review of data (Table 1) reveals that the contribution of fluoride with the toothpaste in nonfluoridated and fluoridated areas is substantial and represents about half of the estimated average total intake and that the estimates for the total daily intake of fluoride in some studies exceed 


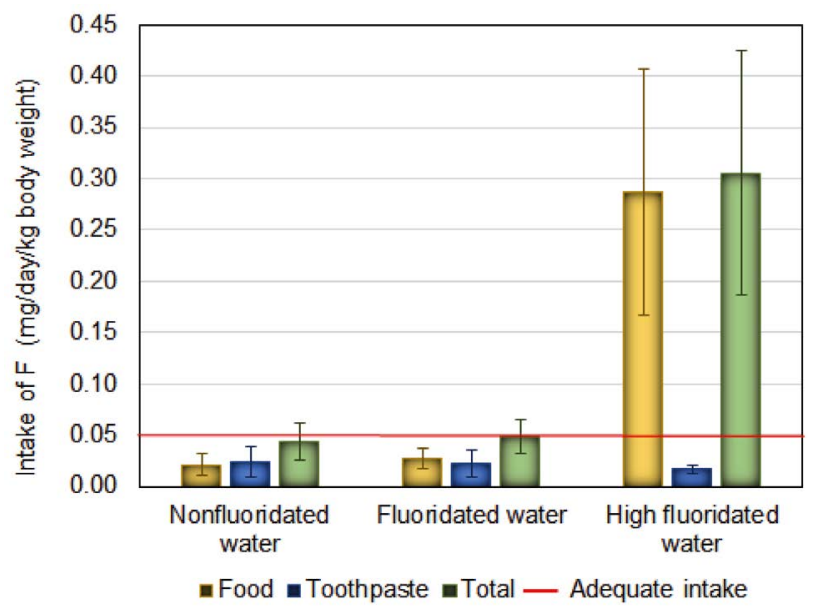

Figure 6: Estimated average total daily intake of fluoride in children from food and toothpaste in areas with nonfluoridated, fluoridated and high fluoridated water

the AI in both nonfluoridated and fluoridated areas. ${ }^{30,243-251}$ The average estimated daily intake of fluoride in nonfluoridated areas is higher and in fluoridated areas lower, than that reported with diet and toothpaste a decade ago $(0.036$ and $0.071 \mathrm{mg} / \mathrm{kg}$ body weight in nonfluoridated and fluoridated areas, respectively). ${ }^{23}$ Possible explanations for these differences are that the recent research (Table 1) has been more focused on: (1) the actual intakes of fluoride, as determined by duplicate diet technique; (2) the total oral fluoride intake including actual intake of fluoride with the toothpaste; and (3) the use of more accurate and precise analytical methods for total fluorine determination.

A comment has to be put on the average estimated total fluoride intakes of $0.260 \mathrm{mg} / \mathrm{kg}$ body weight in areas with fluoride contents in water above $1.2 \mathrm{mg} / \mathrm{l} .{ }^{30,244,249}$ These intakes extremely exceed the AI and also the upper limit ${ }^{50}$ of fluoride daily intake set at $0.10 \mathrm{mg} / \mathrm{kg}$ body weight for children up to the age of eight years.

\section{2. Fluoride Intake in Adults}

The major source of fluoride intake in adults is diet. The data on the total fluoride intake in adults are of older date before $2007 .{ }^{23}$ The average daily total fluoride intake in nonfluoridated areas was then estimated to range from 0.56 to $1.50 \mathrm{mg}$ (average $1.11 \mathrm{mg}$ ) (equivalent to 0.008 0.021 (average 0.016$) \mathrm{mg} / \mathrm{kg}$ body weight for a $70 \mathrm{~kg}$ man). The estimated daily intake of fluoride in fluoridated areas was almost 2-fold higher, being 0.91-3.78 (average 2.07) $\mathrm{mg}$, equivalent to $0.013-0.054$ (average 0.030 ) $\mathrm{mg} / \mathrm{kg}$ body weight for a $70 \mathrm{~kg}$ man. ${ }^{23}$ The average total daily intake of fluoride estimated in our study conducted in Slovenia, where water is nonfluoridated and fluoride content is generally low was $0.73-2.50 \mathrm{mg}$ (average $1.50 \mathrm{mg}$ ) (equivalent to $0.010-0.036$ (average 0.021 ) $\mathrm{mg} / \mathrm{kg}$ body weight for a 70 $\mathrm{kg}$ man). This study is of importance because it is one of the rare studies conducted in adults using duplicate diet technique. ${ }^{149}$

There are exceptions however showing higher fluoride intakes than those listed. Tea can significantly contribute to the total daily intake of fluoride. The content of $\mathrm{F}^{-}$in tea as determined in our recent study ranged between 0.32 and $3.55 \mathrm{mg} / \mathrm{l}$ (average $1.42 \mathrm{mg} / \mathrm{l}) .{ }^{163}$ Figure 7 illustrates average daily intakes of fluoride in adults from food and daily consumption of 11 of tea. Water with $\mathrm{F}^{-}$concentration of $1 \mathrm{mg} / \mathrm{l}$ was considered for preparing tea infusions in fluoridated areas.

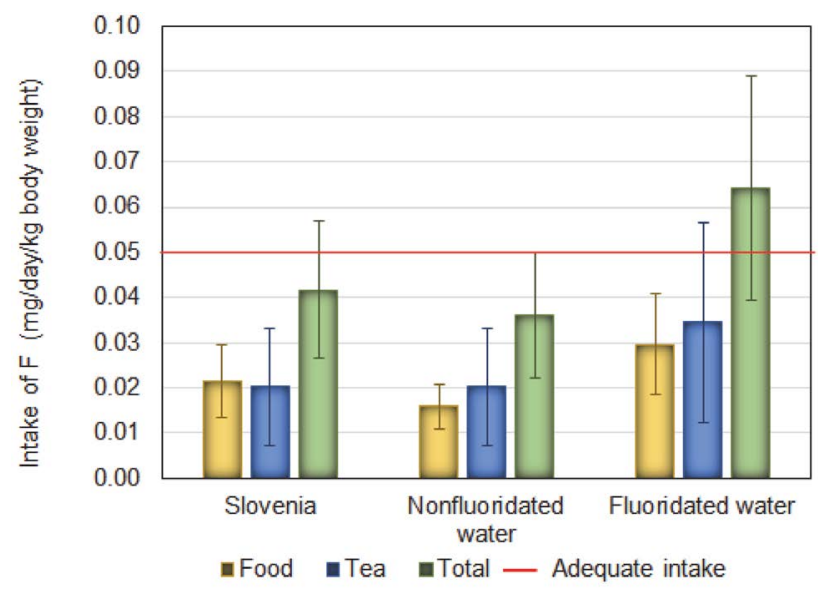

Figure 7: Estimated average total daily intake of fluoride in adults from food and tea in Slovenia and areas with nonfluoridated and fluoridated water

As illustrated in Figure 7, the consumption of tea can significantly contribute to the daily intake of fluoride; the AI for fluoride can be easily exceeded with consumption of higher quantities $(\approx 1)$ of low quality tea. The presented intakes can be however also extremely higher in fluoride endemic areas ${ }^{13,14}$ or in southern China, where brick tea-type fluorosis has even become an urgent public health problem. ${ }^{252,253}$

\section{Adequate Intake of Fluoride}

The basis for setting the adequate intake of fluoride is research by Dean and others. Initial studies conducted in the 1930s and early 1940s were focused on fluoride in water in relation to the appearance of dental fluorosis ${ }^{254-259}$ and then turned to fluoride in water in relation to caries. ${ }^{260,261}$ A "dose response" relationship between fluoride concentration in water supplies and dental fluorosis was established in the 22 cities study ${ }^{261}$ and between fluoride concentration in water supplies and caries in the 21 cities study. ${ }^{261,262}$ Reduction in the average number of dental caries per child was nearly maximal in communities having water fluoride concentrations close to $1.0 \mathrm{mg} / \mathrm{l}$. This is how $1.0 \mathrm{mg} / \mathrm{l}$ of fluoride became the "optimal" concentra- 
tion, i.e. it was associated with a high degree of protection against caries and a low prevalence of the milder forms of enamel fluorosis.

The first conversion of the exposure to fluoride in water supplies to the exposure to fluoride by the intake from water and food was made by McClure. ${ }^{263}$ The daily fluoride intake in children at the age between 1 and 12 years ranged from $0.02-0.10 \mathrm{mg} / \mathrm{kg}$ body weight (average $0.05 \mathrm{mg} / \mathrm{kg}$ body weight). ${ }^{263}$ The way on how this information became interpreted as a recommendation was reviewed by Burt ${ }^{21}$, who concluded that "Despite its dubious genesis, however, empirical evidence suggests that 0.05$0.07 \mathrm{mg}$ fluoride/ $\mathrm{kg}$ body weight/day remains a useful upper limit for fluoride intake in children." The beneficial effects of fluoride on the prevention of dental caries were considered as an appropriate indicator for setting the adequate intake also by EFSA. Thus, the AI of fluoride from all sources (including non-dietary sources), was set at 0.05 $\mathrm{mg} / \mathrm{kg}$ body weight per day for both children and adults, including pregnant and lactating women. ${ }^{22}$ At the same time, it was however noted that reliable and representative data on the European population's total fluoride intake are not available (see also section Daily intake of fluoride). ${ }^{22}$

The current guidelines on the AI of fluoride, which are widely used in authoritative advisory recommendations for many decades, have been recently questioned, mainly because: (1) they were established empirically; (2) sources of ingested fluoride have changed; and (3) the prevalence and severity of dental caries and dental fluorosis have changed. ${ }^{264}$ As a result, the appropriateness of current guidance was addressed, however, no firm conclusions were made. ${ }^{265-267}$

\section{Conclusions - Enough or Too Much Fluoride?}

Many health authorities worldwide consider beneficial effects of fluoride on the prevention of dental caries as an appropriate indicator to set the adequate daily intake of fluoride from all sources between 0.05 and $0.07 \mathrm{mg} / \mathrm{day} / \mathrm{kg}$ body weight. The AI was set based on empirical observations reported by McClure ${ }^{263}$ in 1943, when practically the only source of fluoride was fluoride in water. Today next to water, also tea and other beverages, diet, fluoridated food supplements and dental products can significantly contribute to the daily intake of fluoride. Among different food items processed food, fish and shellfish products might contain considerable contents of fluorine.

Excessive chronic intakes of fluoride can result in the development of fluoride related adverse effects. The primary adverse effects associated with chronic, excess fluoride intake are dental and skeletal fluorosis. As reported, the prevalence of enamel fluorosis including more cases of moderate-to-severe fluorosis is in increase. ${ }^{58,239,240} \mathrm{~A}$ threshold as low as $0.03 \mathrm{mg} / \mathrm{day} / \mathrm{kg}$ body weight has been suggested for the appearance of dental fluorosis, however even this intake will result in a certain, although low, level of fluorosis in a population. ${ }^{39,57}$ Other adverse effects related to the toxicity of fluoride for cells of different tissues include, among others, neurodevelopmental disorders, neurotoxicity, decreased total fertility rate and diabetes.

A review of the recent studies showed that the average total daily intake of fluoride with diet and toothpaste in children living in nonfluoridated and fluoridated areas is $(0.044 \pm 0.026)$ and $(0.048 \pm 0.016) \mathrm{mg} / \mathrm{kg}$ body weight, respectively. These intakes are high enough to assure optimal protection against dental caries, but on the other hand, also high enough to pose a risk for the development of dental fluorosis. There is a lack of recent studies on the daily intake of fluoride in adults. Earlier reported estimates of the average total daily intake of fluoride are 0.016 and $0.030 \mathrm{mg} / \mathrm{kg}$ body weight in nonfluoridated and fluoridated areas, respectively.

Attempts have been made to challenge the guidelines on the AI. However even the most notable ongoing recent study, which started between 1992 and 1995, on the association between fluoride intake, dental caries, and dental fluorosis (Iowa Fluoride Study) ${ }^{268-274}$ after years of extensive investigation, came to the following conclusion: "Given the overlap among caries/fluorosis groups in mean fluoride intake and extreme variability in individual fluoride intakes, firmly recommending "optimal" fluoride intake is problematic". ${ }^{272}$

It is therefore not surprising that the guidelines on the AI of fluoride have been recently questioned ${ }^{264}$ and addressed. ${ }^{265-267}$

Based on the available literature, current recommendations on fluoride intake and the fact that the majority of fluoride benefits can be ascribed to its topical, rather than systemic, effects, it is hard to say whether the current $\mathrm{AI}$ is appropriate, i.e. too low or too high. Knowing this is of crucial importance because the margin between the beneficial and deleterious effects of fluoride appears to be so narrow.

\section{Our Research and Future Directions}

The majority of the fluoride debate is based on the results of the studies which can be regarded by scepticism. Only a few studies reported the use of certified reference materials (CRMs) as a part of the quality assurance system and only two studies with one being contributed by us reported the results together with the measurement uncertainty (MU) estimated according to the Guide to the Expression of Measurement Uncertainty (GUM) ${ }^{117,170,171}$ In addition, in more than eight decades, after McClure ${ }^{275}$ published his first study on fluorine contents in different food items, food growing and processing and our eating habits have changed dramatically. This is also evidenced by 
meaningful difference between the average contents of $\mathrm{F}$ in food consumed in the US and the UK (see Section 7.4.). Thus, more accurate and up to date information on fluoride content in food and possible adverse effects of fluoride in relation to other ions, especially those forming complexes with fluoride are a prerequisite to avoid possible problems related to high intakes.

In our laboratory classical analytics used for determining the composition of bulk material of synthesised compounds containing fluorine ${ }^{118,276-283}$ was extended to thermochemical investigations, ${ }^{118,140,141,280-282,284-287}$ measurement uncertainty evaluation, ${ }^{171}$ determination of fluorine in food $^{149,183}$ and environmental samples ${ }^{7,288,289}$ and nanomaterials. ${ }^{290-294}$

Principles of thermochemistry were used for the estimation of the entropies of formation of fluorine containing aqueous anions ${ }^{285}$ and to discuss ions containing solely fluorine atoms ${ }^{286}$ and oxidation potential of fluorine. ${ }^{287}$ Possible reactions proceeding during total decomposition of fluorine containing materials by pyrohydrolysis, oxygen bomb combustion and alkaline carbonate fusion were suggested and accompanying thermochemistry discussed. Based on this investigation some of the most resistant fluoride minerals towards the total decomposition were suggested..$^{140,141}$

The importance of evaluating the MU according to the GUM in research laboratories was addressed and a procedure for the $\mathrm{MU}$ evaluation for determination of $\mathrm{F}$ in vegetation was suggested. ${ }^{171}$

Our study on fluorine contents in total diet samples is important, since it is one of the few studies on the intakes of fluoride from food in adults which is based on duplicate diet technique. ${ }^{149}$ There is a number of papers reporting the contents of fluoride in tea infusions (Camellia sinensis L.). In our study we extensively investigated contents of total fluorine in tea and its leaching in the form of $\mathrm{F}^{-}$into the infusion with respect to the type of tea and its manufacturing procedure. ${ }^{183}$ As concluded, more attention should be put on consumption of fluoride from food and tea containing beverages.

Our laboratory is devoted also to the environmental issues. In a period of ten years two uncontrolled releases of gaseous fluorides from the industry, which caused damage to the environment and possibly humans via the food chain were identified. ${ }^{7,289}$ The first release also initiated a study on the stress syndrome response of nettle (Urtica dioica L.) grown in fluoride contaminated substrate to fluoride. ${ }^{288}$ Based on these results nettle was suggested as a passive bioindicator for monitoring soil pollution with $\mathrm{F}^{-}$ or for the phytoremediaton by the mechanism of phytoextraction of $\mathrm{F}^{-}$polluted soils.

We also participated in characterization of upconverting, lanthanide-doped, fluoride nanoparticles, which show a great potential in bioimaging. ${ }^{290-294}$

Fluorine research remains relatively sporadic also because of a lack of sound analytical techniques enabling fast and multielemental analysis of $\mathrm{F}$. Thus the predominate method for $\mathrm{F}$ analysis remains fluoride ion selective electrode.

We should be therefore not surprised if a lack of reliable data for $\mathrm{F}$ content in different food items and a lack of regulation regarding $\mathrm{F}$ content in human and animal diets can be noticed, i.e. the only $\mathrm{EU}$ directive related to fluorine in diet addresses the maximum content of $\mathrm{F}$ in animal feed. ${ }^{295-297}$

More research and actions regarding: (1) the content of $\mathrm{F}$ in different food items; (2) reporting the results in accordance to the GUM; (3) the intakes of fluoride and its possible adverse effects in relation to interaction with other food components should be encouraged to provide support for further development and implementation of legislation concerning fluorine.

Despite all the knowledge we currently have we can conclude that one is currently left with the question "Enough or too much fluoride?". Whether the complex nature of the system precludes there ever being a definite answer, remains to be seen.

\section{Declaration of interest: none.}

Funding: This work was supported by the Slovenian Research Agency [ARRS Grant P1-0045, Inorganic Chemistry and Technology].

\section{List of Acronyms}

AAPD, American Academy of Pediatric Dentistry; AAS, Atomic Absorption Spectrometry; AI, Adequate Intake; AR, Average Requirement; CDC, Centers for Disease Control and Prevention; CLD, Certainly Lethal Dose; CRM, Certified Reference Material; CZE, Capillary Zone Electrophoresis; EAPD, European Academy of Paediatric Dentistry; EFSA, European Food Safety Authority; EU, European Union; ${ }^{19} \mathrm{~F}-\mathrm{NMR},{ }^{19} \mathrm{~F}-\mathrm{Nuclear}$ Magnetic Resonance; $F^{-}$, Fluoride Ion; F, Total Fluorine; GUM, Guide to the Expression of Uncertainty in Measurement; HF, Hydrogen Fluoride; HR-CS, High Resolution-Continuum Source; ICP-OES, Inductively Coupled Plasma Optical Emission Spectrometry; ICP-MS, Inductively Coupled Plasma Mass Spectrometry; ICP-MS-MS, Inductively Coupled Plasma Quadrupole Mass Spectrometry; IQ, Intelligence Quotient; ISE, Ion Selective Electrode; LIBS, Laser-Induced Breakdown Spectroscopy; MAS, Molecular Absorption Spectrometry; MU, Measurement Uncertainty; NAA, Neutron Activation Analysis; NIR, Near Infrared Spectroscopy; PTD, Probable Toxic Dose; SD, Standard Deviation; UK, United Kingdom; US, United States; US NAS, United States National Academy of Sciences; WHO, World Health Organization

\section{Author Biographies}

Dona Štepec finished her B.Sc. study (equivalent to M.Sc. after the Bologna reform) in 2013 at the Faculty of 
Chemistry and Chemical Technology at the University of Ljubljana. After graduation, she was employed as a researcher at Faculty of Chemistry and Chemical Technology at the University of Ljubljana on the project in collaboration with BIA Separation d.o.o. for a year and a half. Since 2015 she is enrolled in postgraduate study of Ecotechnology at the Jožef Stefan International Postgraduate School. She is a young researcher at the Department of Inorganic Chemistry and Technology at the Jožef Stefan Institute under mentorship of Prof. Dr. Maja Ponikvar-Svet. Her research activities are focused on determination of fluorine in food and environmental samples and evaluation of measurement uncertainty.

Maja Ponikvar-Svet finished her B.Sc. study in 1994 at the Faculty of Chemistry and Chemical Technology at the University of Ljubljana. After being employed at Merck Sharp \& Dohme, inovativna zdravila d.o.o., for three years she joined Prof. Dr. Boris Žemva's group at the Jožef Stefan Institute, Department of Inorganic Chemistry and Technology in 1994. She received M.Sc. degree in 2000 and completed her PhD thesis in analytical chemistry in 2002 at the University of Ljubljana under mentorship of Prof. Dr. Boris Pihlar. Her research interests are in analytical chemistry of fluoride, measurement uncertainty and thermochemistry. The majority of her scientific work is devoted to fluoride in inorganic materials, food and environment and thermochemical investigations.

\section{References}

1. J. Schmedt auf der Günne, M. Mangstl, F. Kraus, Angew. Chem. Int. Ed. 2012, 51, 7847-7849.

DOI:10.1002/anie.201203515

2. V. R. Celinski, M. Ditter, F. Kraus, F. Fujara, J. Schmedt auf der Günne, Chem. Eur. J. 2016, 22, 18388-18393.

DOI:10.1002/chem.201603402

3. T. A. O’Donnell, in: J. C. Bailar Jr., H. J. Emeléus, R. Nyholm, A. F. Trotman-Dickenson (Eds.): Comprehensive Inorganic Chemistry, $1^{\text {st }}$ Ed., Vol. 5, Pergamon Press, Oxford, England, 1973, pp. 1009-1106.

DOI:10.1016/B978-1-4832-8313-5.50019-X

4. A. W. Davison, L. H. Weinstein, in: A. Tressaud (Ed.): Fluorine and the Environment - Atmospheric Chemistry, Emissions, \& Lithosphere, Vol. 1, Elsevier, Amsterdam, Netherlands, 2006, pp. 251-298.

DOI:10.1016/S1872-0358(06)01008-6

5. E. Álvarez-Ayuso, A. Giménez, J. C. Ballesteros, J. Hazard. Mater. 2011, 192, 1659-1666.

DOI:10.1016/j.jhazmat.2011.06.084

6. W. W. Wenzel, W. E. H. Blum, Soil Sci. 1992, 153, 357-364. DOI:10.1097/00010694-199205000-00003

7. A. Koblar, G. Tavčar, M. Ponikvar-Svet, J. Fluorine Chem. 2011, 132, 755-759. DOI:10.1016/j.jfluchem.2011.05.022

8. M. M. Williamson, East Afr. Med. J. 1953, 30, 217-233.

9. R. J. Thompson, T. B. McMullen, G. B. Morgan, J. Air Pollut.
Control Assoc. 1971, 21, 484-487.

DOI:10.1080/00022470.1971.10469558

10. R. B. Symonds, W. I. Rose, M. H. Reed, Nature 1988, 334, 415-418. DOI:10.1038/334415a0

11. Agency for Toxic Substances and Disease Registry (ATSDR), Toxicological Profile for Fluorides, Hydrogen Fluoride, and Fluorine, Atlanta, United States, 2003.

12. World Health Organization (WHO), Environmental Health Criteria 227, Fluorides, World Health Organization, Geneva, Switzerland, 2002.

13. M. Dessalegne, F. Zewge, Toxicol. Environ. Chem. 2013, 95, 1056-1068. DOI:10.1080/02772248.2013.827685

14. L. Li, K. Luo, Y. Tang, Y. Liu, Environ. Sci. Pollut. Res. 2015, 22, 2031-2040. DOI:10.1007/s11356-014-3485-4

15. Y. Zhou, J. Wang, Z. Gu, S. Wang, W. Zhu, J. L. Aceña, V. A. Soloshonok, K. Izawa, H. Liu, Chem. Rev. 2016, 116, 422-518.

16. A. M. Thayer, Chem. Eng. News 2006, 84, 15-24.

17. National Institute of Dental and Craniofacial Research, The story of fluoridation, https://www.nidcr.nih.gov/health-info/ fluoride/the-story-of-fluoridation (accessed: November 13, 2018)

18. K. Roholm, Fluorine intoxication, NYT Nordisk Forlag, Copenhagen, Denmark, 1937.

19. O. Barbier, L. Arreola-Mendoza, L. M. Del Razo, Chem.-Biol. Interact. 2010, 188, 319-333. DOI:10.1016/j.cbi.2010.07.011

20. N. I. Agalakova, G. P. Gusev, ISRN Cell Biol. 2012, 403835, 1-16. DOI:10.5402/2012/403835

21. B. A. Burt, J. Dent. Res. 1992, 71, 1228-1237. DOI:10.1177/00220345920710051601

22. European Food Safety Authority Panel on Dietetic Products, Nutrition, and Allergies (EFSA NDA), EFSA J. 2013, 11, 1-46.

23. M. Ponikvar, in: A. Tressaud, G. Haufe (Eds.): Fluorine and Health, Molecular Imaging, Biomedical Materials and Pharmaceuticals, Elsevier, Amsterdam, Netherlands, 2008, pp. 487-549.

24. T. M. Marthaler, Acta Med. Acad. 2013, 42, 140-155. DOI:10.5644/ama2006-124.82

25. E. Ziegler, Schweiz. Med. Wochenschr. 1953, 83, 723-724.

26. World Health Organization (WHO), Inadequate or excess fluoride: A major public health concern, World Health Organization, Geneva, Switzerland, 2010.

27. Centers for Disease Control and Prevention (CDC), $M M W R$ Weekly 2008, 57, 737-764.

28. R. P. Ellwood, J. A. Cury, Eur. Arch. Paediatr. Dent. 2009, 10, 170-176. DOI:10.1007/BF03262679

29. American Dental Association Council on Scientific Affairs, JADA 2014, 145, 190-191. DOI:10.14219/jada.2013.47

30. A. Kebede, N. Retta, C. Abuye, S. J. Whiting, M. Kassaw, T. Zeru, M. Tessema, M. Kjellevold, Int. J. Environ. Res. Public Health 2016, 13, 756. DOI:10.3390/ijerph13080756

31. J. Cao, Y. Zhao, J. Liu, R. Xirao, S. Danzeng, Zeguo, S. Zhouma, Ecotoxicol. Environ. Saf. 2003, 56, 222-227.

32. N. Yang, S. Tang, S. Zhang, W. Huang, P. Chen, Y. Chen, Z. Xi, Y. Yuan, K. Wang, Minerals 2017, 7, 219.

DOI: $10.3390 / \min 7110219$

33. M. Ando, M. Tadano, S. Asanuma, K. Tamura, S. Matsushi- 
ma, T. Watanabe, T. Kondo, S. Sakurai,R. Ji, C. Liang, S. Cao, Environ. Health Perspect. 1998, 106, 239-244.

DOI:10.1289/ehp.98106239

34. J. Yi, J. Cao, J. Fluorine Chem. 2008, 129, 76-81. DOI:10.1016/j.jfluchem.2007.11.001

35. X. Qin, S. Wang, M. Yu, L. Zhang, X. Li, Z. Zuo, X. Zhang, L. Wang, J. Environ. Public Health 2009, 969764.

36. N. Kakumanu, S. D. Rao, N. Engl. J. Med. 2013, 368, 1140. DOI:10.1056/NEJMicm1200995

37. S. Isaac, F. Brudevold, F. A. Smith, D. E. Gardner, J. Dent. Res. 1958, 37, 254-263. DOI:10.1177/00220345580370020901

38. O. Fejerskov, A. Thylstrup, M. J. Larsen, Acta Odontol. Scand. 1981, 39, 241-249. DOI:10.3109/00016358109162285

39. T. Aoba, O. Fejerskov, Crit. Rev. Oral. Biol. Med. 2002, 13, 155-170. DOI:10.1177/154411130201300206

40. K. Koo, Adv. Dent. Res. 2008, 20, 17-21. DOI:10.1177/154407370802000105

41. R. E. Marquis, S. A. Clock, M. Mota-Meira, FEMS Microbiol. Rev. 2003, 26, 493- 510. DOI:10.1111/j.1574-6976.2003.tb00627.x

42. D. R. Carter, G. S. Beaupre, J. Bone Miner. Res. 1990, 5 (Suppl 1), 177-184. DOI:10.1002/jbmr.5650051372

43. B. L. Riggs, S. F. Hodgson, W. M. O’Fallon, E. Y. Chao, H. W. Wahner, J. M. Muhs, S. L. Cedel, L. J. Melton III, N. Engl. J. Med. 1990, 322, 802-809.

DOI:10.1056/NEJM199003223221203

44. C. H. Søgaard, L. Mosekilde, A. Richards, L. Mosekilde, Bone 1994, 15, 393-399. DOI:10.1016/8756-3282(94)90815-X

45. J. E. Aaron, M. C. de Vernejoul, J. A. Kanis, Bone 1991, 12, 307-310. DOI:10.1016/8756-3282(91)90015-B

46. S. Peckham, N. Awofeso, Sci. World J. 2014, 293019, 1-10. DOI:10.1155/2014/293019

47. S. Lecheny, 'Adverse Event,' Not the Same as 'Side Effect', https://www.pharmacytimes.com/contributor/shelby-leheny-pharmd-candidate-2017/2017/02/adverse-event-notthe-same-as-side-effect, (accessed: November 20, 2018)

48. rachita, Difference Between Side Effects and Adverse Effects, http://www.differencebetween.net/science/health/disease-health/difference-between-side-effects-and-adverse-effects/, (accessed: November 20, 2018)

49. A. F. Danil de Namor, I. Abbas, in: A. Tressaud (Ed.): Fluorine and the Environment, Agrochemicals, Archaeology, Green Chemistry \& Water, Vol. 2, Elsevier, Amsterdam, Netherlands, 2006, pp. 81-119.

DOI:10.1016/S1872-0358(06)02003-3

50. European Food Safety Authority Panel on Dietetic Products, Nutrition, and Allergies (EFSA NDA), EFSA J. 2005, 192, 1-65.

51. G. M. Whitford, in: M. A. R. Buzalaf (Ed.): Monographs in Oral Science, Vol. 22, Karger, Basel, Switzerland, 2011, pp. 66-80.

52. H. C. Hodge, F. A. Smith, in: J. H. Simons (Ed.): Fluorine Chemistry, Academic Press, New York, United States, 1965, pp. 1-364.

53. National Research Council, Acute Exposure Guidelines Levels for Selected Airborne Chemicals, Vol. 4, The National Academies Press, Washington, D.C., United States, 2004.
54. D. Peters, R. Miethchen, J. Fluorine Chem. 1996, 79, 161-165. DOI:10.1016/S0022-1139(96)03484-7

55. K. Heard, R. E. Hill, C. B. Cairns, R. C. Dart, J. Toxicol. Clin. Toxic. 2001, 39, 349-353. DOI:10.1081/CLT-100105154

56. J. Ly, R. D. Shin, Fluoride toxicity mechanism, https://emedicine.medscape.com/article/814774-overview, (accessed: November 16, 2018)

57. V. Baelum, O. Fejerskov, F. Manji, M. J. Larsen, Tandlaegebladet. 1987, 91, 452-456.

58. P. DenBesten, W. Li, in: M. A. R. Buzalaf (Ed.): Monographs in Oral Science, Vol. 22, Karger, Basel, Switzerland, 2011, pp. 81-96.

59. N. Molina-Frechero, M. Nevarez-Rascón, A. Nevarez-Rascón, R. González-González, M. E. Irigoyen-Camacho, L. Sánchez-Pérez, S. López-Verdin, R. Bologna-Molina, Int. J. Environ. Res. Public Health 2017, 14, 73.

DOI:10.3390/ijerph14010073

60. American International Medical University, Fluorosis: Causes, Diagnosis, Management and Prevention, https://www. aimu.us/2017/08/15/fluorosis-causes-diagnosis-management-and-prevention/, (accessed: November 16, 2018)

61. P. Grandjean, P. J. Landrigan, Lancet Neurol. 2014, 13, 330338. DOI:10.1016/S1474-4422(13)70278-3

62. J. Gelinas, M. Allukian Jr, Lancet Neurol. 2014, 13, 647-648. DOI:10.1016/S1474-4422(14)70119-X

63. P. Grandjean, P. J. Landrigan, Lancet Neurol. 2014, 13, 648. DOI:10.1016/S1474-4422(14)70121-8

64. P. K. Shivaprakash, K. Ohri, H. Noorani, J. Indian Soc. Pedod. Prev. Dent. 2011, 29, 117-120.

DOI:10.4103/0970-4388.84683

65. A. Aravind, R. S. Dhanya, A. Narayan, G. Sam, V. J. Adarsh, M. Kiran, J. Int. Soc. Prev. Community Dent. 2016, 6 (Suppl 3), S237-S242. DOI:10.4103/2231-0762.197204

66. M. Bashash, D. Thomas, H. Hu, E. A. Martinez-Mier, B. N.. Sanchez, N. Basu, K. E. Peterson, A. S. Ettinger, R. Wright, Z. Zhang, Y. Liu, L. Schnaas, A. Mercado-García, M. M. Téllez-Rojo, M. Hernández-Avila, Environ. Health Perspect. 2017, 125, 097017-1-097017-12. DOI:10.1289/EHP655

67. C. N. Still, P. Kelley, Neurotoxicology 1980, 1, 125-131.

68. W. F. Forbes, L. M. Hayward, N. Agwani, Lancet 1991, 338, 1592-1593. DOI:10.1016/0140-6736(91)92411-T

69. R. L. Blaylock, Fluoride 2004, 37, 301-314.

70. I. D. Akinrinade, A. E. Memudua, O. M. Ogundele, Pathophysiol. 2015, 22, 105-115.

DOI:10.1016/j.pathophys.2015.03.001

71. K. Hasan, S. Alam, J. Mirkovic, F. Hossain, Bioinformation 2018, 14, 68-74. DOI:10.6026/97320630014068

72. S. C. Freni, J. Toxicol. Environ. Health Part A 1994, 42, 109121. DOI:10.1080/15287399409531866

73. K. Fluegge, J. Water Health. 2016, 14, 864-877. DOI:10.2166/wh.2016.012

74. Z. Kheradpisheh, M. Mirzaei, A. H. Mahvi, M. Mokhtari, R. Azizi, H. Fallahzadeh, M. H. Ehrampoush, Sci. Rep. 2018, 8, 1-7. DOI:10.1038/s41598-018-20696-4

75. J. Ghosh, J. Das, P. Manna, P.C. Sil, Toxicol. In Vitro, 2008, 22, 1918-1926. DOI:10.1016/j.tiv.2008.09.010 
76. World Health Organization (WHO), Air Quality Guidelines for Europe, $2^{\text {nd }}$ Ed., World Health Organization, Geneva, Switzerland, 2000.

77. World Health Organization (WHO), Environmental Health Criteria 36, Fluorine and Fluorides, World Health Organization, Geneva, Switzerland, 1984.

78. E. A. Martínez, J. Evidence-Based Complementary Altern. Med. 2012, 17, 28-32.

79. J. Gutknecht, A. Walter, Biochim. Biophys. Acta 1981, 644, 153-156. DOI:10.1016/0005-2736(81)90071-7

80. G. M. Whitford, The Metabolism and Toxicity of Fluoride, $2^{\text {nd }}$ Ed., Karger, Basel, Switzerland, 1996.

81. J. Nopakun, H. H. Messer, Nutr. Res. 1990, 10, 771-779. DOI:10.1016/S0271-5317(05)80826-7

82. J. Nopakun, H. H. Messer, V. Voller, J. Nutr. 1989, 119, 14111417. DOI:10.1093/jn/119.10.1411

83. J. Ekstrand, M. Ehrnebo, L. O. Boréus, Clin. Pharmacol. Ther. 1978, 23, 329-337. DOI:10.1002/cpt1978233329

84. A. Maguire, F. V. Zohouri, J. C. Mathers, I. N. Steen, P. N. Hindmarch, P. J. Moynihan, J. Dent. Res. 2005, 84, 989-993. DOI: $10.1177 / 154405910508401104$

85. F. L. Cerklewski, Nutr. Res. 1997, 17, 907-929. DOI:10.1016/S0271-5317(97)00057-2

86. J. Ekstrand, M. Ehrnebo, Eur. J. Clin. Pharmacol. 1979, 16, 211-215. DOI:10.1007/BF00562063

87. C. J. Spak, J. Ekstrand, D. Zylberstein, Caries Res. 1982, 16, 249-256. DOI:10.1159/000260605

88. K. Trautner, G. Siebert, Archs. Oral Biol. 1986, 31, 223-228. DOI:10.1016/0003-9969(86)90053-1

89. A. Goyal, K. Gauba, A. Tewari, J. Indian Soc. Pedod. Prev. Dent. 1998, 16, 1-6.

90. K. Trautner, J. Einwag, J. Dent. Res. 1989, 68, 72-77. DOI: $10.1177 / 00220345890680011201$

91. E. R. Shulman, M. Vallejo, Pediatr. Dent. 1990, 12, 237-240.

92. L. S. Kaminsky, M. C. Mahoney, J. Leach, J. Melius, M. J. Miller, Crit. Rev. Oral Biol. Med. 1990, 1, 261-281.

DOI:10.1177/10454411900010040501

93. G. M. Whitford, Adv. Dent. Res. 1994, 8, 5-14.

DOI:10.1177/08959374940080011001

94. J. Ekstrand, M. Ehrnebo, J. Occup. Med. 1983, 25, 745-748. DOI:10.1097/00043764-198310000-00014

95. A. Villa, M. Anabalon, V. Zohouri, A. Maguire, A. M. Franco, A. Rugg-Gunn, Caries Res. 2010, 44, 60-68. DOI:10.1159/000279325

96. J. Ekstrand, L. I. Hardell, C. J. Spak, Caries Res. 1984, 18, 8792. DOI:10.1159/000260753

97. J. Ekstrand, E. E. Ziegler, S. E. Nelson, S. J. Fomon, Adv. Dent. Res. 1994, 8, 175-180. DOI:10.1177/08959374940080020701

98. A. Oliveby, F. Lagerlōf, J. Ekstrand, C. Dawes, J. Dent. Res. 1989, 68, 146-149. DOI:10.1177/00220345890680020901

99. World Health Organization (WHO), Report of an Expert Committee on Oral Health Status and Fluoride Use, WHO Technical Report Series 846, World Health Organization, Geneva, Switzerland, 1994.

100. United States National Research Council (US NRC), Biologic Markers in Reproductive Toxicology, National Academy
Press, Washington, D.C., United States, 1989.

101. World Health Organization (WHO), Biomarkers and Risk Assessment: Concepts and Principles, Environmental Health Criteria 155, World Health Organization, Geneva, Switzerland, 1993.

102. A. J. Rugg-Gunn, A. E. Villa, M. A. R. Buzalaf, in: M. A. R. Buzalaf (Ed.): Monographs in Oral Science, Vol. 22, Karger, Basel, Switzerland, 2011, pp. 37-51.

103. J. P. Pessan, M. A. R. Buzalaf, in: M. A. R. Buzalaf (Ed.): Monographs in Oral Science, Vol. 22, Karger, Basel, Switzerland, 2011, pp. 52-65.

104. A. Mehta, Indian J. Dent. 2013, 4, 207-210. DOI:10.1016/j.ijd.2013.05.002

105. R. C. Agali, S. B. Shintre, IJSS Rep. Rev. 2016, 2, 49-52.

106. G. M. Whitford, in: G. M. Whitford (Ed.): Monographs in Oral Science, Vol. 16, Karger, Basel, Switzerland, 1996, pp. 1-9.

107. J. Ekstrand, in: O. Fejerskov, B. A. Burt (Eds.): Fluoride in Dentistry, $2^{\text {nd }}$ Ed., Munksgaard, Copenhagen, Denmark, 1996, pp. 55-68.

108. D. M. O’Mullane, R. J. Baez, S. Jones, M. A. Lennon, P. E. Petersen, A. J. Rugg-Gunn, H. Whelton, G. M. Whitford, Community Dent. Health 2016, 33, 69-99.

109. World Health Organization (WHO), Basic Methods for Assessment of Renal Fluoride Excretion in Community Prevention Programmes for Oral Health, World Health Organization, Geneva, Switzerland, 2014.

110. A. Oliveby, F. Lagerlof, J. Ekstrand, C. Dawes, Arch. Oral. Biol. 1989, 34, 191-194. DOI:10.1016/0003-9969(89)90007-1

111. A. Oliveby, F. Lagerlof, J. Ekstrand, C. Dawes, Caries Res. 1989, 23, 243-246. DOI:10.1159/000261185

112. G. M. Whitford, Schweiz. Monatsschr. Zahnmed. 2005, 115, 685-689.

113. Z. Kokot, D. Drzewiecki, Fluoride 2000, 33, 196-204.

114. S. S. Sankhala, R. Harshwal, P. Paliwal, A. Agarwal, Fluoride 2014, 47, 235-240.

115. N. H. Joshi, C. G. Ajithkrishnan, Int. J. Trichology. 2018, 10, 71-75. DOI:10.4103/ijt.ijt_91_17

116. H. Nakagaki, Y. Koyama, Y. Sakakibara, J. A. Weatherell, C. Robinson, Arch. Oral. Biol. 1987, 32, 651-654. DOI:10.1016/0003-9969(87)90039-2

117. Joint Committee for Guides in Metrology (JCGM), Evaluation of Measurement Data - Guide to the Expression of Uncertainty in Measurement (GUM), 2008.

118. J. F. Liebman, M. Ponikvar, Struct. Chem. 2005, 16, 521-528. DOI:10.1007/s11224-005-5179-5

119. J. Belisle, Science 1981, 212, 1509-1510. DOI:10.1126/science.7233235

120. D. R. Taves, Nature 1968, 217, 1050-1051. DOI:10.1038/2171050b0

121. P. Venkateswarlu, L. Singer, W. D. Armstrong, Anal. Biochem. 1971, 42, 350-359. DOI:10.1016/0003-2697(71)90047-9

122. P. Venkateswarlu, Adv. Dent. Res. 1994, 8, 80-86. DOI:10.1177/08959374940080011401

123. H. H. Willard, O. B. Winter, Ind. Eng. Chem., Anal. Ed. 1933, 5,7-10. DOI:10.1021/ac50081a006 
124. G. Pietzka, P. Ehrlich, Angew. Chem. 1953, 65, 131-134. DOI:10.1002/ange.19530650504

125. M. A. Wade, S. S. Yamamura, Anal. Chem. 1965, 37, 12761287. DOI:10.1021/ac60229a028

126. L. H. Andersson, B. Gelin, FOA Rep. 1967, 1, 1-5.

127. M. J. Nardozzi, L. L. Lewis, Anal. Chem. 1961, 33, 12611264. DOI:10.1021/ac60177a040

128. R. L. Clements, G. A. Sergeant, P. J. Webb, Analyst 1971, 66, 51-54. DOI:10.1039/an9719600051

129. L. Singer, W. D. Armstrong, Anal. Chem. 1954, 26, 904-906. DOI:10.1021/ac60089a029

130. D. R. Taves, Talanta 1968, 15, 969-974. DOI:10.1016/0039-9140(68)80097-9

131. P. Venkateswarlu, Anal. Chem. 1992, 64, 346-349. DOI:10.1021/ac00028a005

132. J. J. Bailey, Anal. Chem. 1961, 33, 1760-1762. DOI:10.1021/ac60180a040

133. J. Thomas, H. J. Gluskoter, Anal. Chem. 1974, 46, 13211323. DOI: $10.1021 / \mathrm{ac} 60345 \mathrm{a} 038$

134. P. Venkateswarlu, Anal. Biochem. 1975, 68, 512-521. DOI:10.1016/0003-2697(75)90646-6

135. L. Singer, R. H. Ophaug, Anal. Chem. 1977, 49, 38-40. DOI:10.1021/ac50009a018

136. J. Cornog, H. Hopson, J. Chem. Educ. 1930, 7, 618-623. DOI:10.1021/ed007p618

137. R. Bock, A Handbook of Decomposition Methods in Analytical Chemistry, Blackie Group, London, England, 1979.

138. S. R. Grobler, A. J. Louw, Caries Res. 1998, 32, 378-384. DOI:10.1159/000016474

139. R. A. Rocha, D. Rojas, M. J. Clemente, A. Ruiz, V. Devesa, D. Vélez, J. Agric. Food Chem. 2013, 61, 10708-10713. DOI:10.1021/jf403728r

140. M. Ponikvar, J. F. Liebman, Struct. Chem. 2006, 17, 75-78. DOI:10.1007/s11224-006-9023-3

141. D. Pavlović, M. Ponikvar-Svet, J. F. Liebman, Struct. Chem. 2018, 29, 1247-1254.

DOI:10.1007/s11224-018-1148-7

142. P. Venkateswarlu, J. Dent. Res. 1990, 69, 514-521.

DOI:10.1177/00220345900690S105

143. D. O'Hagan, Chem. Soc. Rev. 2008, 37, 308-319. DOI:10.1039/B711844A

144. P. Venkateswarlu, Anal. Chem. 1982, 54, 1132-1137. DOI:10.1021/ac00244a028

145. D. R. Taves, Talanta, 1968, 15, 1015-1023. DOI:10.1016/0039-9140(68)80109-2

146. H. B. Li, F. Chen, Fresenius' Z. Anal. Chem. 2000, 368, 501504. DOI:10.1007/s002160000478

147. M. S. Frant, J. W. Ross Jr., Science, 1966, 154, 1553-1554. DOI:10.1126/science.154.3756.1553

148. Thermo Fisher Scientific, Thermo Scientific Orion Fluoride Ion Selective Electrode, Thermo Fisher Scientific, Waltham, US, 2016.

149. M. Ponikvar, V. Stibilj, B. Žemva, Food. Chem. 2007, 103, 369-374. DOI:10.1016/j.foodchem.2006.07.032

150. H. Small, T. S. Stevens, W. C. Bauman, Anal. Chem. 1975, 47, 1801-1809. DOI:10.1021/ac60361a017
151. J. Belisle, D. F. Hagen, Anal. Biochem. 1978, 87, 545-555. DOI:10.1016/0003-2697(78)90704-2

152. M. Haldimann, B. Zimmerli, Anal. Chim. Acta 1993, 282, 589-601. DOI:10.1016/0003-2670(93)80124-4

153. J. Musijowski, B. Szostek, M. Koc, M. Trojanowicz, J. Sep. Sci. 2010, 33, 2636-2644. DOI:10.1002/jssc.201000179

154. J. Weiss, S. Reinhard, C. Pohl, C. Saini, L. Narayaran, J. Chromatogr. A 1995, 706, 81-92.

DOI:10.1016/0021-9673(94)01162-8

155. T. A. Biemer, N. Asral, A. Sippy, J. Chromatogr. A 1997, 771, 355-359. DOI:10.1016/S0021-9673(97)00066-6

156. V. F. Samanidou, C. K. Zacharis, I. N. Papadoyannis, J. Liq. Chrom. \& Rel. Technol. 2002, 25, 803-818.

DOI: $10.1081 /$ JLC-120003037

157. W. Guo, L. Jin, S. Hu, Q. Guo, J. Agric. Food Chem. 2017, 65, 3406-3412. DOI:10.1021/acs.jafc.7b00535

158. H. W. Kuo, W. G. Chang, Y. S. Huang, J. S. Ali, Bull. Environ. Contam. Toxicol. 1999, 62, 677-684.

DOI:10.1007/s001289900927

159. P. Politzer, J. Am. Chem. Soc. 1969, 91, 6235-6237. DOI:10.1021/ja01051a006

160. B. Welz, F. G. Lepria, R. G..O. Araujoa, S. L. C. Ferreira, M. D. Huang, M. Okruss, H. Becker-Ross, Anal. Chim. Acta 2009, 647, 137-148. DOI:10.1016/j.aca.2009.06.029

161. W. Guo, L. Jin, S. Hu, Q. Guo, J. Agric. Food Chem. 2017, 65, 3406-3412. DOI:10.1021/acs.jafc.7b00535

162. L. Guanghan, W. Qiongling, W. Xiaogang, Z. Tong, Y. Xin, Food Chem. 1999, 66, 519-523.

DOI:10.1016/S0308-8146(99)00091-6

163. M. Čerňanská, P. Tomčík, Z. Jánǒsíková, M. Rievaja, D. Bustin, Talanta 2011, 83, 1472-1475. DOI:10.1016/j.talanta.2010.11.026

164. R. Chavali, N. S. K. Gunda, S. Naicker, S. K. Mitra, Anal. Chem. Res. 2015, 6, 26-31. DOI:10.1016/j.ancr.2015.10.003

165. K. Fukushi, Y. Fujita, J. Nonogaki, J. Tsujimoto, T. Hattori, H. Inui, V. P. Beškoski, H. Hotta, M. Hayashi, T. Nakano, Anal. Bioanal. Chem. 2018, 410, 1825-1831.

DOI:10.1007/s00216-017-0838-0

166. E. Tamburini, C. Tagliati, T. Bonato, S. Costa, C. Scapoli, P. Pedrini, Sensors 2016, 16, 1216. DOI:10.3390/s16081216

167. D. Deng, P. Deng, X. Wang, X. Hou, Spectrosc. Lett. 2009, 42, 334-340. DOI:10.1080/00387010903185462

168. F. Mostafaei, F. E. McNeill, D. R. Chettle, W. V. Prestwich, Physiol. Meas. 2013, 34, 1329-1341.

DOI:10.1088/0967-3334/34/10/1329

169. Joint Committee on Guides for Metrology (JCGM), International Vocabulary of Metrology - Basic and General Concepts and Associated Terms (VIM), 2002.

170. A. R. Sousa, M. A. Trancoso, Accred. Qual. Assur. 2005, 10, 430-438. DOI:10.1007/s00769-005-0009-4

171. D. Štepec, G. Tavčar, M. Ponikvar-Svet, J. Fluorine Chem. 2019, 217, 22-28. DOI:10.1016/j.jfluchem.2018.08.010

172. International Organization for Standardization (ISO), Guide 35: Reference materials - General and statistical principles for certification, Geneva, Switzerland, 2006.

173. Scientific Committee on Health and Environmental Risks 
(SCHER), Critical review of any new evidence on the hazard profile, health effects, and human exposure to fluoride and the fluoridating agents of drinking water, European Commission, Brussels, Belgium, 2010.

174. Health and Ecological Criteria Division, Office of Water, Fluoride: Exposure and relative source contribution analysis, U.S. Environmental Protection Agency, Washington, D.C., United States, 2010.

175. World Health Organization (WHO), Guidelines for drinking-water quality, $2^{\text {nd }}$ Ed., World Health Organization, Geneva, Switzerland, 1993.

176. World Health Organization (WHO), Fluoride in drinking-water, World Health Organization, Geneva, Switzerland, 2004

177. European Commission, Off. J. Eur. Communities: Legis. 1998, 330, 32-54.

178. United States Public Health Service (USPHE), Public Health Rep. 2015, 130, 318-331.

179. Centers for Disease Control and Prevention (CDC), $M M W R$ Weekly 1999, 48, 241-243.

180. European Commission, Off. J. Eur. Communities: Legis. 2003, 126, 34-39.

181. Food and Drug Administration (FDA), Code of Federal Regulations, https://www.accessdata.fda.gov/scripts/cdrh/ cfdocs/cfcfr/CFRSearch.cfm, (accessed: November 14, 2018)

182. K. F. Fung, Z. Q. Zhang, J. W. C. Wong, M. H. Wong, Environ. Pollut. 1999, 104, 197-205.

DOI:10.1016/S0269-7491(98)00187-0

183. A. Koblar, G. Tavčar, M. Ponikvar-Svet, Food Chem. 2012, 130, 286-290. DOI:10.1016/j.foodchem.2011.07.037

184. L. Chan, A. Mehra, S. Saikat, P. Lynch, Food Res. Int. 2013, 51, 564-570. DOI:10.1016/j.foodres.2013.01.025

185. C. Peng, H. Cai, X. Zhu, D. Li, Y. Yang, R. Hou, X. Wan, J. Food Sci. 2016, 81, H235-H239.

DOI:10.1111/1750-3841.13180

186. D. T. Waugh, W. Potter, H. Limeback, M. Godfrey, Int. J. Environ. Res. Public Health. 2016, 13, 259.

DOI:10.3390/ijerph13030259

187. T. Shyu, J. Chen, J. Food, Agric. Environ. 2013, 11, 178-183.

188. M. P. Whyte, Am. J. Med. 2006, 119, 189-190. DOI:10.1016/j.amjmed.2005.05.028

189. Y. Liu, A. Maguire, G. Tianqui, S. Yanguo, F. V. Zohoori, Nutr. Health 2017, 23, 25-32.

DOI:10.1177/0260106016685726

190. S. C. C. Lung, P. K. Hsiao, K. M. Chiang, J. Expo. Anal. Environ. Epidemiol. 2003, 13, 66-73.

DOI:10.1038/sj.jea.7500259

191. C. Fojo, M. E. Figueira, C. M. M. Almeida, Food Addit. Contam., Part A 2013, 30, 705-712.

192. I. Rodríguez, A. Hardisson, S. Paz, C. Rubio, A. J. Gutiérrez, J. R. Jaudenes, A. Burgos, C. Revert, J. Food Comps. Anal. 2018, 72, 97-103.

193. M. C. Kiritsy, S. M. Levy, J. J. Warren, N. Guha-Chowdhury, J. R. Heilman, T. Marshall T, J. Am. Dent. Assoc. 1996, 127, 895-902. DOI:10.14219/jada.archive.1996.0347
194. M. D. Jiménez-Farfán, J. C. Hernández-Guerrero, J. P. Loyola-Rodríguez, C. Ledesma-Montes, Int. J. Paediatr. Dent. 2004, 14, 260-266. DOI:10.1111/j.1365-263X.2004.00564.x

195. J. Opydo-Szymaczek, J. Opydo, Food Chem. Toxicol. 2010, 48, 2702-2706. DOI:10.1016/j.fct.2010.06.043

196. S. Omar, J. Chen, B. Nelson, W. Okumura, W. Zhang, J. Dent. Child. 2012, 81, 20-26.

197. J. R. Heilman, M. C. Kiritsy, S. M. Levy, J. S. Wefel, J. Am. Dent. Assoc. 1999, 130, 1593-1599.

DOI:10.14219/jada.archive.1999.0098

198. M. M. Martin Delgado, A. Hardisson de la Torre, R. Alvarez Marante, J. Food Comps. Anal. 1992, 5, 172-180.

199. S. Warnakulasuriya, C. Harris, S. Gelbier, J. Keating, T. Peters, Clin. Chim. Acta 2002, 320, 1-4.

DOI:10.1016/S0009-8981(02)00043-8

200. I. Rodríguez, J. R. Jaudenes, A. Hardisson, S. Paz, C. Rubio, A. J. Gutiérrez, A. Burgos, C. Revert, Biol. Trace Elem. Res. 2018, 181, 178-183. DOI:10.1007/s12011-017-1191-Z

201. M. I. Rodríguez Gómez, A. Hardisson de La Torre, A. Burgos Ojeda, R. Álvarez Marante, L. Díaz-Flores, Eur. Food Res. Technol. 2003, 216, 145-149.

DOI:10.1007/s00217-002-0622-y

202. O. B. Martínez, C. Díaz, T. M. Borges, E. Díaz, J. P. Pérez, Food Addit. Contam. 1998, 15, 893-897.

DOI:10.1080/02652039809374726

203. S. Paz, J. R. Jaudenes, A. J. Gutiérrez, C. Rubio, A. Hardisson, C. Revert, Biol. Trace Elem. Res., 2017, 178, 153-159. DOI:10.1007/s12011-016-0910-1

204. N. Ozbek, S. Akman, LWT Food Sci. Technol. 2015, 61, 112116.

205. A. W. Burgstahler, M. A. Robinson, Fluoride 1997, 30, 142146.

206. C. Liu, L. E. Wyborny, J. T. Chan, Fluoride 1995, 28, 10-16.

207. M. A. R. Buzalaf, J. P. Pessan, R. Fukushima, A. Dias, H. M. Rosa, J. Appl. Oral. Sci. 2006, 14, 38-42. DOI:10.1590/S1678-77572006000100008

208. O. B. Dirks, J. M. P. A. Jongeling-Eijndhoven, T. D. Flissebaalje, I. Gedalia, Caries Res. 1974, 8, 181-186. DOI:10.1159/000260106

209. P. Gupta, N. Gupta, K. Meena, N. J. Moon, P. Kumar, R. Kaur, J. Clin. Diagn. Res. 2015, 9, 5-7.

210. T. G. Kazi, K. D. Brahman, H. I. Afridi, F. Shah, M. B. Arain, Environ. Sci. Pollut. Res. 2018, 25, 12909-12914. DOI:10.1007/s11356-018-1563-8

211. C. McKnight-Hanes, D. H. Leverett, S. M. Adair, C. P. Shields, Pediatr. Dent. 1988, 10, 189-194.

212. H. Lal, F. V. Zohoori, N. Omid, V. R. Valentine, A. Maguire, Br. Dent. J. 2014, 217, E8. DOI:10.1038/sj.bdj.2014.736

213. O. Rirattanapong, P. Rirattanapong, Southeast Asian J. Trop. Med. Public Health 2016, 47, 160-164.

214. National Research Council (NRC), Fluoride in drinking water: a scientific review of EPA's standards, National Academies Press, Washington, D.C., United States, 2006.

215. H. Poureslami, P. Khazaeli, A. H. Mahvi, K. Poureslami, P. Poureslami, J. Haghani, M. Aghaei, Fluoride 2016, 49, 485494. 
216. B. Spittle, Fluoride 2016, 49, 471.

217. P. Cressey, J. Public Health Dent. 2010, 70, 285-291. DOI:10.1111/j.1752-7325.2010.00183.x

218. Nutrient Data Laboratory, Beltsville Human Nutrition Research Center, Agricultural Research Service, of selected beverages and foods, Release 2, Baltimore, United States, 2005.

219. V. Zohoori, A. Maguire, Database of the Fluoride (F) content of Selected Drinks and Foods in the UK, Newcastle University and Teesside University, United Kingdom, 2015.

220. F. V. Zohoori, A. Maguire, Caries Res. 2016, 50, 331-336. DOI:10.1159/000445981

221. P. A. San Filippo, G. C. Battistone, Clin. Chim. Acta 1971, 31, 453-457. DOI:10.1016/0009-8981(71)90418-9

222. L. Singer, R. H. Ophaug, B. F. Harland, Am. J. Clin. Nutr. 1980, 33, 328-332. DOI:10.1093/ajcn/33.2.328

223. P. Varo, P. Koivistoinen, Acta Agric. Scand. 1980, Suppl. 22, 165-171.

224. D. R. Taves, Br. J. Nutr. 1983, 49, 295-301. DOI:10.1079/BJN19830038

225. L. Singer, R. H. Ophaug, J. Agric. Food Chem. 1986, 34, 510513. DOI:10.1021/jf00069a035

226. H. Lopez, J. M. Navia, Caries Res. 1988, 22, 210-216. DOI:10.1159/000261108

227. R. W. Dabeka, A. D. McKenzie, J. AOAC Int. 1995, 78, 897909.

228. E. Newbrun, J. Dent. Res. 1992, 71, 1255-1265. DOI:10.1177/00220345920710052001

229. G. M. Whitford, J. Dent. Res. 1987, 66, 1056-1060. DOI:10.1177/00220345870660051501

230. H. Pollick, J. Calif. Dent. Assoc. 2013, 41, 395-404.

231. T. M. Marthaler, P. E. Petersen, Int. Dent. J. 2013, 55, 351358. DOI:10.1111/j.1875-595X.2005.tb00045.x

232. F. C. Sampaio, S. M. Levy, in: M. A. R. Buzalaf (Ed.): Monographs in Oral Science, Vol. 22, Karger, Basel, Switzerland, 2011, pp. 133-145.

233. C. A. Yeung, L. Y. Chong, A. M. Glenny, Cochrane Database Syst. Rev. 2015, 3, CD003876.

234. C. A. Yeung, J. L. Hitchings, T. V. Macfarlane, A. G. Threlfall, M. Tickle, A. M. Glenny, Aust. Dent. J. 2005, 50, 286-287. DOI:10.1111/j.1834-7819.2005.tb00376.x

235. A. I. Ismail, H. Hasson, J. Am. Dent. Assoc., JADA 2008, 139, 1457-1468. DOI:10.14219/jada.archive.2008.0071

236. C. M. Vargas, J. Evid. Base Dent. Pract. 2011, 11, 18-20. DOI:10.1016/j.jebdp.2010.11.022

237. The European Academy of Paediatric Dentistry (EAPD), Eur. Arch. Paediatr. Dent. 2009, 10, 129-135. DOI:10.1007/BF03262673

238. American Academy of Pediatric Dentistry (AAPD), Ref. Man. 2014, 37, 15-16.

239. D. H. Leverett, Science 1982, 217, 26-30. DOI:10.1126/science.7089534

240. R. G. Rozier, J. Public Health. Dent. 1999, 59, 239-246. DOI:10.1111/j.1752-7325.1999.tb03276.x

241. E. A. Martinez-Mier, K. L. Spencer, B. J. Sanders, J. E. Jones, A. E. Soto-Rojas, A. M. Tomlin, L. A. Vinson, J. A. Weddell,
G. J. Eckert, Community Dent. Oral. Epidemiol. 2017, 45, 251-257. DOI:10.1111/cdoe.12283

242. S. M. Levy, J. Eichenberger-Gilmore, J. J. Warren, E. Letuchy, B. Broffitt, T. A. Marshall, T. Burns, M. Willing, K. Janz, J. C. Torner, Community Dent. Oral Epidemiol. 2009, 37, 416426. DOI:10.1111/j.1600-0528.2009.00478.x

243. A. B. P. Miziara, S. T. Philippi, F. M. Levy, M. A. R. Buzalaf, Community Dent. Oral Epidemiol. 2009, 37, 305-315. DOI:10.1111/j.1600-0528.2009.00477.x

244. F. V. Zohoori, M. A. R. Buzalaf, C. A. B. Cardoso, K. P. K. Olympio, F. M. Levy, L. T. Grizzo, D. F. B. Mangueira, F. C. Sampaio, A. Maguire, Eur. J. Oral Sci. 2013, 121, 457-464. DOI:10.1111/eos.12070

245. O. Ibiyemi, F. V. Zohoori, R. A. Valentine, A. Maguire, Community Dent. Oral Epidemiol. 2018, 46, 482-491. DOI:10.1111/cdoe.12396

246. E. Oganessian, R. Ivancakova, E. Lencova, Z. Broukal, BMC Public Health 2011, 11, 768-773. DOI:10.1186/1471-2458-11-768

247. A. Maguire, F. V. Zohouri, P. N. Hindmarch, J. Hatts, P. J. Moynihan, Community Dent. Oral Epidemiol. 2007, 35, 479-488. DOI:10.1111/j.1600-0528.2006.00366.x

248. P. F. T. Oliveira, J. A. Cury, C. V. Lima, G. C. Vale, M. D. M. Lima, L. F. A. D. Moura, M. S. Moura, Braz. Oral Res. 2018, 32, e26.

249. L. Abuhaloob, A. Maguire, P. Moynihan, Int. J. Paediatr. Dent. 2015, 25, 127-135. DOI:10.1111/ipd.12108

250. N. Omid, A. Maguire, W. T. O'Hare, F. V. Zohoori, Community Dent. Oral Epidemiol. 2017, 45, 12-19.

DOI:10.1111/cdoe.12254

251. C. V. Lima, J. A. Cury, G. C. Vale, M. D. M. Lima, L. D. A. D. Moura, M. S. Moura, Caries Res. 2015, 49, 640-646. DOI:10.1159/000442029

252. Z. Fan, Y. Gao, W. Wang, H. Gong, M. Guo, S. Zhao, X. Liu, B. Yu, D. Sun, J. Epidemiol. 2016, 26, 57-63.

DOI:10.2188/jea.JE20150037

253. A. Tressaud, Fluorine, a Paradoxical Element, Progress in Fluorine Science, Vol. 5, Elsevier, Amsterdam, Netherlands, 2019.

254. H. T. Dean, R. M. Dixon, C. Cohen, Public Health Rep. 1935, 50, 424-442. DOI:10.2307/4581503

255. H. T. Dean, E. Elvove, Public Health Rep. 1935, 50, 17191729. DOI: $10.2307 / 4581707$

256. H. T. Dean, J. Am. Med. Assoc. 1936, 107, 1269-1272. DOI:10.1001/jama.1936.02770420007002

257. H. T. Dean, E. Elvove, Am. J. Public Health 1936, 26, 567575. DOI:10.2105/AJPH.26.6.567

258. H. T. Dean, E. Elvove, Public Health Rep. 1937, 52, 1249 1264. DOI: $10.2307 / 4582298$

259. H. T. Dean, in: S. M. Gordon (Ed.): Dental Science and Dental Art, Lea and Febiger, Philadelphia, United States, 1938, pp. 387-414.

260. H. T. Dean, P. Jay, F. A. Arnold Jr., E. Elvove, Pub. Health Rep. 1941, 56, 761-792. DOI:10.2307/4583693

261. H. T. Dean, P. Jay, F. A. Arnold Jr., E. Elvove, Pub. Health Rep. 1942, 57, 1155-1194. DOI:10.2307/4584182 
262. H. T. Dean, in: F. R. Moulton (Ed.): Dental caries and fluorine, Science Press, American Association for the Advancement of Science, Washington D.C., US, 1946, pp. 5-31.

263. F. J. McClure, Am. J. Dis. Child. 1943, 66, 362-369. DOI:10.1001/archpedi.1943.02010220015002

264. A. J. Rugg-Gunn, Adv. Dent. Res. 2018, 29, 142-143. DOI:10.1177/0022034517750588

265. M. A. R. Buzalaf, Adv. Dent. Res. 2018, 29, 157-166. DOI:10.1177/0022034517750850

266. I. Mejàre, Adv. Dent. Res. 2018, 29, 167-176. DOI:10.1177/0022034517750589

267. A. J. Spencer, L. G. Do, U. Mueller, J. Baines, M. Foley, M. A. Peres, Adv. Dent. Res. 2018, 29, 144-156. DOI:10.1177/0022034517750592

268. S. M. Levy, F. J. Kohout, M. C. Kiritsy, J. R. Heilman, W. S. Wefel, J. Am. Dent. Assoc. 1995, 126, 1625-1632. DOI:10.14219/jada.archive.1995.0110

269. S. M. Levy, M. C. Kiritsy, S. L. Slager, J. J. Warren, J. Public Health. Dent. 1998, 58, 228-233.

DOI:10.1111/j.1752-7325.1998.tb02998.x

270. S. M. Levy, J. J. Warren, C. S. Davis, H. L. Kirchner, M. J. Kanellis, J. S. Wefel, J. Public Health Dent. 2001, 61, 70-77. DOI:10.1111/j.1752-7325.2001.tb03369.x

271. S. M. Levy, J. J. Warren, B. Broffitt, J. Public Health. Dent. 2003, 63, 211-220. DOI:10.1111/j.1752-7325.2003.tb03502.x

272. J. J. Warren, S. M. Levy, M. J. Kanellis, J. Public Health Dent. 2002, 62, 109-114.

DOI:10.1111/j.1752-7325.2002.tb03430.x

273. J. J. Warren, S. M. Levy, B. Broffitt, J. E. Cavanaugh, M. J. Kanellis, K. Weber-Gasparoni, J. Public Health Dent. 2009, 69, 111-115. DOI:10.1111/j.1752-7325.2008.00108.x

274. M. R. Franzman, S. M. Levy, J. J. Warren, B. Broffitt, Pediatr. Dent. 2004, 26, 87-92.

275. F. J. McClure, Fluorides in food and drinking water, National Institute of Health Bulletin 172, United States Treasury Department, Public Health Service, Washington, D.C., United States, 1939.

276. B. Sedej, Talanta, 1976, 23, 335-336. DOI:10.1016/0039-9140(76)80209-3

277. M. Ponikvar, B. Sedej, B. Pihlar, B. Žemva, Anal. Chim. Acta 2000, 418, 113-118. DOI:10.1016/S0003-2670(00)00942-9

278. M. Ponikvar, B. Pihlar, B. Žemva, Talanta 2002, 58, 803-810. DOI:10.1016/S0039-9140(02)00371-5
279. M. Ponikvar, B. Pihlar, B. Žemva, J. Fluorine Chem. 2003, 122, 215-217. DOI:10.1016/S0022-1139(03)00090-3

280. M. Ponikvar, B. Žemva, J. F. Liebman, J. Fluorine Chem. 2003, 123, 217-220. DOI:10.1016/S0022-1139(03)00139-8

281. M. Ponikvar, B. Sedej, J. F. Liebman, Eur. J. Inorg. Chem. 2004, 1349-1352. DOI:10.1002/ejic.200300632

282. M. Ponikvar, J. F. Liebman, H. D. B. Jenkins, Eur. J. Inorg. Chem. 2004, 3273-3276. DOI:10.1002/ejic.200400150

283. P. Benkič, H. D. B. Jenkins, M. Ponikvar-Svet, Z. Mazej, Eur. J. Inorg. Chem. 2006, 1084-1092.

DOI:10.1002/ejic.200500856

284. M. Ponikvar-Svet, J. F. Liebman, Struct. Chem. 2005, 16, 587-591. DOI:10.1007/s11224-005-6099-0

285. M. Ponikvar-Svet, H. D. B. Jenkins, J. F. Liebman, Struct. Chem. 2007, 18, 883-889.

DOI:10.1007/s11224-007-9189-3

286. M. Ponikvar-Svet, K. F. Edwards, J. F. Liebman, Acta Chim. Slov. 2013, 60, 471-483.

287. M. Ponikvar-Svet, D. N. Zeiger, J. F. Liebman, Struct. Chem. 2015, 26, 1621-1628. DOI:10.1007/s11224-015-0647-z

288. A. Koblar, G. Tavčar, M. Ponikvar-Svet, J. Fluorine Chem. 2015, 172, 7-12. DOI:10.1016/j.jfluchem.2015.01.006

289. D. Štepec, G. Tavčar, M. Ponikvar-Svet, Environ. Pollut. 2019, DOI: DOI:10.1016/j.envpol.2019.02.046

290. O. Plohl, B. Majaron, M. Ponikvar-Svet, D. Makovec, D. Lisjak, Acta Chim. Slov. 2015, 62, 789-795.

DOI:10.17344/acsi.2015.1508

291. D. Lisjak, O. Plohl, M. Ponikvar-Svet, B. Majaron, RSC Adv. 2015, 5, 2046-2069.

292. D. Lisjak, O. Plohl, J. Vidmar, B. Majaron, M. Ponikvar-Svet, Langmuir 2016, 32, 8222-8229.

DOI:10.1021/acs.langmuir.6b02675

293. O. Plohl, S. Kralj, B. Majaron, E. Fröhlich, M. Ponikvar-Svet, D. Makovec, D. Lisjak, Dalton Trans. 2017, 46, 6975-6984. DOI:10.1039/C7DT00529F

O. Plohl, M. Kraft, J. Kovač, B. Belec, M. Ponikvar-Svet, C. Würth, D. Lisjak, U. Resch-Genger, Langmuir 2017, 33, 553-560. DOI:10.1021/acs.langmuir.6b03907

294. European Commission, Off. J. Eur. Communities: Legis. 2002, 140, 10-21.

295. European Commission, Off. J. Eur. Communities: Legis. 2005, 318, 19-24.

296. European Union, Off. J. Eur. Communities: Legis. 2015, 31, $11-17$.

\section{Povzetek}

Fluor v obliki fluoridov je v naravi zelo razširjen in zato predstavlja neizogiben del našega okolja. Znano je, da ima fluor v majhnih količinah koristne učinke na zdravje zob. Po drugi strani lahko čezmerni kronični vnos povzroči neželene učinke, vključno $\mathrm{z}$ razvojem zobne fluoroze pri otrocih in/ali kostne fluoroze pri otrocih in odraslih. Primeren dnevni vnos fluora, ki temelji na empiričnih raziskavah, je $0,05 \mathrm{mg} / \mathrm{dan} / \mathrm{kg}$ telesne mase, vendar je prag med koristnimi in škodljivimi učinki ozek. Znanje o strupenosti fluorida je kljub številnim raziskavam še vedno pomanjkljivo. V tem preglednem članku so opisani vloga in učinki fluorida na zdravje ljudi. Podanih je nekaj s fluoridom povezanih kontroverznosti in predlog smernic za bodoče raziskave. 